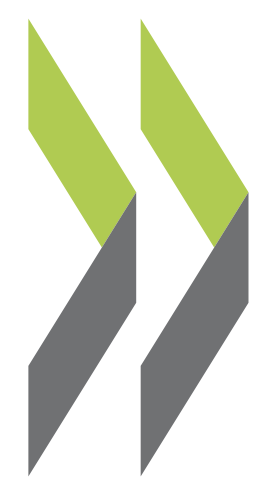

OECD Science, Technology and Industry Working Papers $2001 / 01$

\title{
Economic Growth and Technological Change: An Evolutionary Interpretation
}

\section{Bart Verspagen}


ECONOMIC GROWTH AND TECHNOLOGICAL CHANGE: AN EVOLUTIONARY INTERPRETATION

\section{Bart Verspagen}


DSTI/DOC(2001)1

\title{
ECONOMIC GROWTH AND TECHNOLOGICAL CHANGE: AN EVOLUTIONARY INTERPRETATION
}

\author{
Bart Verspagen ${ }^{1}$ \\ Eindhoven Centre for Innovation Studies (ECIS), Eindhoven University of Technology, PO Box 513, 5600 MB \\ Eindhoven, the Netherlands \\ and \\ Maastricht Economic Research Institute on Innovation and Technology (MERIT), PO Box 616, \\ 6200 MD Maastricht, the Netherlands, \\ e-mail: bart.verspagen@merit.unimaas.nl, Internet: http://meritbbs.unimaas.nl/verspagen.html
}

This paper provides a perspective from evolutionary economic theory on recent growth differences in the OECD area. The empirical analysis contained in the paper offers a number of findings. First, the United States seems to be diverging from the other OECD countries, while the latter are still, by and large, converging to the OECD average. Second, the estimated model of evolutionary growth suggests that convergence based on the assimilation of foreign technology is becoming a more active process. R\&D now seems to be crucial for catching-up and is no longer an activity that is unequivocally associated with moving the world technological frontier. Third, differences between countries in terms of pure technological competencies, i.e. patenting, have become more important in explaining growth differentials. These trends suggest that the absorption of foreign technology requires more active efforts, and that technological differences between countries translate more easily into growth rate differentials. Both tendencies increase the probability of divergence in the world economy. The evolutionary approach to economic growth also suggests that radical innovations are important for economic growth, and especially for changes in trend growth. The paper also examines the adjustment of the OECD markets for high-technology content goods, in particular ICT hardware, instruments and pharmaceuticals. The analysis shows that some degree of polarisation was occurring in these markets during the 1990s, suggesting divergence in technological competencies as well as divergence in terms of trade performance.

\section{CROISSANCE ÉCONOMIQUE ET CHANGEMENT TECHNOLOGIQUE: UNE INTERPRÉTATION ÉVOLUTIONNISTE}

\section{Bart Verspagen}

Ce document fournit la perspective de théorie économique évolutionniste sur les différences récentes de croissance entre les pays de l'OCDE. L'analyse empirique menée dans le rapport offre un certain nombre de résultats. En premier lieu, les États-Unis semblent diverger des autres pays de l'OCDE, alors que ces derniers convergent, généralement, vers la moyenne de l'OCDE. Deuxièmement, le modèle évolutionniste de croissance estimé suggère que la convergence basée sur l'assimilation de la technologie étrangère devient un processus plus actif. La R-D semble maintenant être cruciale pour rattraper un retard et n'est plus une activité qui vise systématiquement à déplacer la frontière technologique du monde. Troisièmement, les différences entre les pays en termes de compétences technologiques pures, c'est-à-dire les dépôts de brevets, sont devenues plus importantes dans l'explication des différentiels de croissance. Ces tendances suggèrent que l'absorption de la technologie étrangère exige des efforts plus importants, et que les différences technologiques entre les pays se traduisent plus facilement en termes de différentiels de taux de croissance. Ces deux tendances augmentent la probabilité de divergence dans l'économie mondiale. L'approche évolutionniste de la croissance économique suggère également que les innovations radicales sont importantes pour la croissance économique, et plus particulièrement pour les changements de tendance de croissance. Cet article examine également l'ajustement des marchés de l'OCDE pour les biens de technologie de pointe, en particulier l'équipement en TIC (les technologies de l'information et de la communication), les instruments de mesure et les produits pharmaceutiques. L'analyse prouve qu'un certain degré de polarisation s'est produit sur ces marchés pendant les années 90, suggérant une divergence des compétences technologiques aussi bien qu'une divergence en termes de performances commerciales. 
DSTI/DOC(2001)1

\section{Introduction}

The aim of this paper is to apply insights from evolutionary economic theory to the question of what can explain recent trends in economic growth, with emphasis on the role of technological change. Obviously, a basic question that precedes this is "what is evolutionary economic theory"? The answer to this is not simple. In mainstream economics, it is clear that the term "neo-classical growth model" refers to Solow's model (e.g. Solow, 1970), and the term "endogenous growth models" refers to a relatively limited set of models, that can reasonably be described by perhaps four prototypes (Romer, 1990; Lucas, 1988; Aghion and Howitt, 1992; Rebelo, 1991). However, even when attention is limited to growth theory, it is impossible to define "the evolutionary growth model".

There are various reasons for this. The most basic one is that the very centre of the evolutionary argument is that growth is a process that takes place in historical time. This implies that economic growth interacts with, and is influenced by, many factors that are more or less outside the economic domain (culture, institutions, science). It also means that an important part of evolutionary economic theory consists of ex post explanation of events and developments, rather than strict ex ante prediction of growth paths. Evolutionary economics is to a large extent a branch of theory that has to rely on methods that go behind the standard toolkit of economic modelling, and this leads to a situation in which many different approaches flourish. This makes it hard to speak about "the evolutionary approach".

This is not to say that evolutionary economists dislike formal modelling. There are many formal evolutionary growth models (see Silverberg and Verspagen, 1998, for a survey). But each and every one of these models is a strong abstraction of the much richer set of evolutionary theories described above. This necessarily implies that the models usually focus on rather narrow issues as compared to non-formal evolutionary economic theory, which in turn means that all these models are rather different in terms both of the set-up and the issues analysed.

Hence, the best one can do in terms of summarising the evolutionary economic literature on growth in a paper like this is to draw upon the big issues in the literature, and leave most of the details out of the picture. Hopefully, such a broad sweep will yield a limited number of issues that can usefully be tackled in an empirical way. Certainly, the biggest issue in evolutionary economics is technological change. This is why this paper will focus largely on the relationship between technology and economic growth.

What then is the relation to mainstream (neo-classical) ${ }^{2}$ economics? I would argue that over the 1990s, some convergence between the two schools of thought has been taking place. Heertje (1993) put it as follows: "neo-Schumpeterians have been productive in their criticism of the neo-classical scheme on the basic of an evolutionary approach, but the questions they have raised have been addressed more or less successfully by many scholars, who have close links with the neo-classical tradition (...) I would not be surprised to see the present Schumpeterian mood to be part of mainstream economics before the end of this century" (pp. 273-275).

Although, with hindsight, I would argue that Heertje was probably a bit too optimistic (pessimistic?) about the degree of ultimate convergence between neo-classical and evolutionary economics, it is undoubtedly true that a number of the topics that occupied the minds of evolutionary economists in the 1970s and 1980s have been picked up in the new growth school. This is why a number of the topics that I will present below as evolutionary topics may look familiar to some readers, even if they have not been reading the evolutionary literature before. For example, the issue of convergence and catching-up by means of international technology spillovers has recently been analysed in a neo-classical model by Benhabib and Spiegel (1994), but had been around in the evolutionary literature at least since Pavitt and Soete (1982). I will discuss this idea further in Section 4 below. Similarly, the notion of general purpose technologies "introduced" by Helpman and Trajtenberg (1994) bears large similarities to the issue of 
radical innovations that I consider crucial in evolutionary economics (e.g. Kleinknecht, 1987; Freeman, Clark and Soete, 1982). I will use the notion of radical innovations throughout this paper.

I will not touch upon these similarities in the remainder of this paper, nor go into the issue of "intellectual property rights" of either school over the topics covered here. What ultimately concerns the present paper is what evolutionary theory has to say about the empirics of economic growth. I consider the question of whether or not recent neo-classical economics has similar things to say as less important for the current analysis.

Section 2 will cover in some detail the issue of what characterises evolutionary economics. As argued above, it is impossible to do justice to the variety found in the field in such a short part of the paper. I will therefore present four issues that I consider to be absolutely essential to evolutionary growth theory. Each of these issues will be picked up in a subsequent section, where I will try to provide empirical substance to the argument and to draw some conclusions about recent patterns of growth. The final section will attempt to draw the issues together again, and to present an evolutionary interpretation of the signs we have regarding the future trends of economic growth in the OECD area.

\section{Evolutionary economics}

The term evolutionary economics has been used in many different contexts. At one level, the term refers to a set of formal economic theories that makes use of biological metaphors. In these theories, the biological notions of natural selection and (random) genetic mutation are applied to economic processes such as industrial dynamics (Dosi, Marsili et al., 1995) or economic growth (Silverberg and Verspagen, 1998). An early overview of the methods and issues in this branch of literature is given in Silverberg (1988).

Two concepts are crucial in these models. First, heterogeneity between economic agents or economic units, be it firms, consumers, countries or even technologies. This assumption criticises the standard neo-classical concept of the representative agent. Economic agents or units (I will refer to firms from now on) are different, and how these differences translate into economic growth or the dynamics of industry selection is where the second concept comes in. The second concept is economic selection as a counterpart of natural selection. Firms that have "better" strategies than other firms will tend to grow, while firms with "worse" strategies will tend to lose market share. Which strategies are good or bad is a matter of theory, and many different aspects of this have been explored in recent evolutionary models.

One consequence of this perspective on economic dynamics is that the natural way of looking at the economy is in terms of population dynamics. Evolutionary economic theory does not have much to say about the strategy of individual firms, at least not in the traditional way that economic theory wants to explain behaviour. In neo-classical economics, firm behaviour results from profit maximisation. What comes out of this is a concrete prediction of firm behaviour in terms of, for example, how much labour is demanded, or much will be invested in machinery. These quantities are explained in terms of the marginal returns to these factors in the production process, and the prevailing market prices.

Evolutionary economic models, instead, usually revert to the concept of "rules of thumb", as a description of economic behaviour under bounded rationality (Nelson and Winter, 1982). Rules of thumb take the form of a fixed ratio of, for example, investment to profits, or R\&D to profits. What determines the exact value of these ratios is not explained at the level of the individual firm. Instead, the distribution of the rules of thumb over the complete firm population evolves endogenously (at least in the more sophisticated evolutionary economic models). For example, in Silverberg and Verspagen (1994), under the influence of economic selection, the distribution of the R\&D sales ratio converges to a fixed value that depends on technological opportunities and spillovers. 
A second interpretation of the term "evolutionary economics" takes the analogy to biology much less strictly. In this case, the term is used to refer to a set of theories, more often informal than formal, which pay particular attention to the role of technology and institutions in the process of economic growth. Usually, these contributions draw inspiration from Schumpeter's (1912) notion of disequilibrium dynamics resulting from the introduction of (basic) innovations. Examples of this approach are Fagerberg (1987), Fagerberg (1988a), Freeman and Soete (1987) or Dosi, Pavitt and Soete (1990).

The central theme in this literature is that one cannot make a useful distinction between "economic" and "non-economic" factors when trying to explain economic growth. These authors think of the "social system" as composed of different "domains", e.g. the techno-economic domain and the socio-institutional domain (Perez, 1983), or the separate domains of technology, economy and institutions (Dosi, 1984). Each of these domains has its own dynamics and explanatory processes, but what is important is that the domains exert strong mutual influences. Examples of such interaction are the impact of European integration (a process that started very much as a way of stabilising Europe politically after the 1940s) on economic growth (Fagerberg, Guerrieri et al., 1999), the impact of culture on regional innovation systems (Saxenian, 1994), or the influence of firm organisation on economic growth (Von Tunzelmann, 1995). In this view, any "model" that limits itself to pure economic factors (such as R\&D, capital investment or human capital) provides a far too narrow perspective on economic growth.

Thus, the perspective offered by these theories is that of the world economy as a process of constant transformation, very much in the sense of classical authors such as Marx and Smith. Technologies and institutions change over time, and what drives economic growth in one era (e.g. economies of scale in relation to mass production) might become much less important, or might be substituted by a different factor (e.g. network economies) in a different era. In terms of economic growth rates, such a process is quite different from the neo-classical notion of steady-state growth.

OECD (2000), under the heading "The changing role of innovation in growth performance", discusses a number of transformations that are good examples of the processes I have in mind in the present discussion of evolutionary economics. Among the factors mentioned, there are shortening technology cycles, changes in financial markets enabling easier financing of innovative activities (venture capital), the increasing role of networks and alliances in technology development, and the closer link to science. I will not discuss these factors in any detail here, but will instead try to investigate how these (and other) changes affect the causal links between innovation indicators and economic growth (Section 4 below).

One example of a non-steady-state evolutionary growth process is the Schumpeterian idea of long waves. Originating from Schumpeter (1939), and later refined by contributions such as Freeman, Clark and Soete (1982), Kleinknecht (1987) and van Duijn (1983), this hypothesis states that the introduction of basic innovations are clustered in time. A "bunch" of innovations may lead an upswing of economic growth once it creates a bandwagon of follow-up incremental innovations. Wolff's law (Freeman, 1982) of decreasing marginal technological opportunities ultimately brings a slowdown of economic growth once the new technological paradigm (the term is Dosi's, 1982) has been diffused throughout the economy. Although this is clearly a technology-driven theory of economic growth, the attention to other than pure economic or technological factors is large. Perez (1983) and Von Tunzelmann (1995) are particularly strong examples of approaches where the notion of technological paradigms is linked to broad institutional change, firm strategy or industry dynamics.

Long waves are only one alternative to a steady state. Many researchers in the evolutionary school would argue against a strict cyclical interpretation of economic growth (e.g. Freeman, Clark and Soete, 1982; Silverberg and Lehnert, 1994). In this weaker interpretation of Schumpeter's theory of innovation and growth, periods of rapid and slow growth take over from each other, but the exact duration of different phases depends on specific historical and institutional factors. 
Can we draw any common conclusions from this diverse set of perspectives that can be grouped under the heading of evolutionary economics? I would propose the following four:

1. Economic growth is first of all a process of transformation, not of convergence to a steady-state growth path. The transformation of capitalism involves interaction of the economic sphere with other domains, such as science and technology, and institutions. This has three major implications. First, that differences in economic growth (both over time and between countries) are hard to predict $e x$ ante, but often have clear underlying explanatory factors ex post. Second, that in the long run, economic growth is not a process of general convergence. One might indeed observe historical periods of convergence during times when institutions and technological developments allow this, but periods of divergence of economic growth must also be expected. Third, any distinction between trend growth and cyclical variations around the trend is problematic.

2. Technology is a key factor shaping economic growth and the changes in growth rates. Obviously, this in itself is something that evolutionary economics has in common with new growth theory. What is specific to evolutionary economics, however, is the question of how technological change adds to the variability of trend growth rates signalled in point 1 above. In order to answer this question, two issues seem to be relevant. The first is the distinction between radical and incremental innovation. Radical innovations open up new possibilities for long-run changes in the trend rate of economic growth. When radical (or basic) innovations occur, they disrupt the existing economic structure and dependencies in the economy. This leads to changes in the growth rate that are (again) hard to predict in a detailed way ex ante. Incremental innovations are associated with the diffusion of the radical innovations throughout the economy, and they depend crucially on the specific historical and institutional context.

The second issue is the (stylised) distinction between innovation and imitation. Technology cannot be fully appropriated by the firm that develops an innovation. In time, technological knowledge spills over to other firms and other nations. While innovation (the development of new technology) may lead to divergence between firms or nations, imitation tends to erode differences in technological competencies, and hence lead to convergence. When diffusion of innovations takes time and depends on "fuzzy" institutional factors such as those mentioned above, the exact mix between innovation and diffusion may lead to turbulent growth paths [Silverberg and Verspagen (1995) provide a quantitative model that illustrates this point].

3. The third conclusion follows from the notion of radical and incremental innovation. In opening up new possibilities for economic activities, radical innovation will often create new industries, or drastically revitalise existing industries. Incremental innovation is then one of the driving forces behind the growth of these industries. In other words, the process of economic growth is characterised by structural change. Explaining the growth of new industries and the decline of old ones is an important aspect of an evolutionary theory of economic growth (Los, 1999). ${ }^{3}$

4. The final conclusion follows from the notion of economic selection. In evolutionary economics, competition is seen as a process that is important in terms of its dynamics, not its long-run tendency. The dynamics of selection shape economic growth. This leads to two important points. First, as was argued above, it is obviously necessary to adopt a perspective of population dynamics - or, in the case of economic growth, a sample of countries. Second, adjustment of market shares in world markets is an important aspect of an evolutionary explanation of economic growth. 


\section{Economic growth: transformation or steady state?}

What evidence is there for the evolutionary hypothesis of economic growth as a non-steady-state process of constant transformation? As argued in the previous section, this question is very much related to non-economic variables such as institutions and culture. Measurement of these factors is difficult, although not impossible. However, I will approach the issue from a purely quantitative perspective, focusing only on growth rates of GDP and GDP per capita, thus providing rather indirect "evidence".

The issue of changes in the trend rate of growth has been investigated in a recent set of papers (e.g. Crafts and Mills, 1996, and the references there). In general, the methodology used to investigate this question is to estimate the log of GDP or GDP per capita as a (linear) function of time, where the slope of the estimated relation ship gives the trend growth rate. Varying this slope for different periods, and testing for the statistical significance of the differences, gives an indication of trend changes in economic growth. Although this method has intuitive appeal, it has one major disadvantage in the present context. The method posits trend breaks as discontinuous events: the trend growth rate is assumed to change suddenly from one year to the other, and then to stay constant for a longer period. From an evolutionary point of view, one would like to investigate the possibility of smoother changes in the trend.

One way of dealing with this problem is to estimate the trend growth rate as a time varying parameter, as can be done using the Kalman filter. In this way, one may specify the trend growth rate itself as a (stochastic) function that changes annually. This is the method used here. As is usually the case, GDP and GDP per capita are modelled as a loglinear function of time. However, both the constant and the slope of this relation are modelled as time varying parameters in a Kalman filter model, i.e. these parameters are assumed to change on a yearly basis by a stochastic process. ${ }^{4}$

Figure 1 gives the Kalman filter estimations for 18 countries for which long time series are available in Maddison (1995). For the most recent years (up to 1998), Maddison's data were updated with data developed by the Groningen Growth and Development Centre. ${ }^{5}$ The figures give the growth rate of GDP per capita (left axis, dark line) and the growth rate of GDP (right axis, light line). The results indicate that there is indeed great variability in the "trend" growth rates for these countries over time. Most evidently, the two world wars cause violent interruptions of trends. For many countries (Australia, Austria, Belgium, Germany, ${ }^{6}$ Japan, New Zealand, Switzerland, the United Kingdom and the United States), the start of the $20^{\text {th }}$ century is a period of high growth. The early 1910s show radical breaks, usually with rapidly falling trend growth rates. With the two wars, the roaring Twenties and the Great Depression of the 1930s, the next 35 years are turbulent, with no clear steady state settling in.

After 1950, the European countries show a common pattern of rapidly increasing trend growth rates. Australia and Japan also show this pattern. In most cases, this strong increase in the trend brings the countries involved onto a path with growth rates that are higher than ever experienced in the $20^{\text {th }}$ century. This is very clearly the case for France, Italy, Japan, Spain and Sweden.

The 1970s bring the well-documented break with the golden age of the 1950s and 1960s. In most countries, trend growth settled down at a relatively constant level (Canada, Denmark, New Zealand and Switzerland are the main exceptions). It is notable, however, that compared to the end of the golden age, the trend growth rates in most countries are at a similar or slightly lower level. What is different in the 1970s and 1980s compared to the previous period is that the trend growth rates no longer increase.

The 1990s show some ripples in many countries. Obviously, compared to the time span of the graph, this period is rather short for any firm judgement about possible reversions of the trend. What is interesting, however, is the fact that the estimated trends vary greatly across countries. On the one hand, Germany, Italy and Japan seem to experience a decrease in the trend. Denmark, Finland, Norway, the 
United Kingdom and the United States, on the other hand, seem to show signs of an increase in trend growth.

OECD (2000) investigates changes in the trend rate of growth between the 1980s and the 1990s. The method used in that report was to compare the rate of growth in 1980-90 to that of 1990-98. Based on the difference in growth between these two periods, three groups of countries can be distinguished (increasing growth, equal growth, decreasing growth). The general finding of the analysis is that there are indeed large differences across countries, with a substantial number of countries in each of the groups. Ireland, the Netherlands, Norway, Australia, Denmark and the United States emerge as countries with increasing growth. Comparing this to the results obtained here, one sees some interesting similarities and differences. For Australia, the present analysis confirms increasing growth (for GDP per capita), but seen in the longer historical perspective, this is a process that follows on quite smoothly from the past. The upswing in growth in the Netherlands, Norway and the United States seems more fragile in the present analysis than in the OECD analysis. On the other hand, the present analysis seems to indicate increasing growth rates in Finland and the United Kingdom (both classified as falling growth in the OECD analysis).

In summary, the Kalman filter estimations seem to show that the concept of steady-state growth is not very useful from an empirical point of view. Growth paths of countries show a high degree of variability over time. Periods of rapid and slow(er) growth take turns, without, however, a clear cyclical pattern with fixed periodicity. There are some features of historical growth patterns that seem to be shared by most countries: generally erratic patterns of trend growth before 1940, a long period of increasing trend growth rates after the Second World War, and slowdown of growth from the mid-1970s. Despite these common patterns, there are important differences between countries with respect to the timing of changes in the trend, the level of growth rates, and the detailed shape of the patterns. Moreover, there are quite a few exceptions to these common patterns. Interestingly, the 1990s are a clear example of the variability of growth trends between countries. In some countries, one sees a clear pattern of take off of growth rates, while in others the flat trend of the 1970s and 1980s is continued. 
Figure 1. Trend growth rates of GDP per capita (light line, left axis) and GDP (dark line, right axis), estimated with a Kalman filter
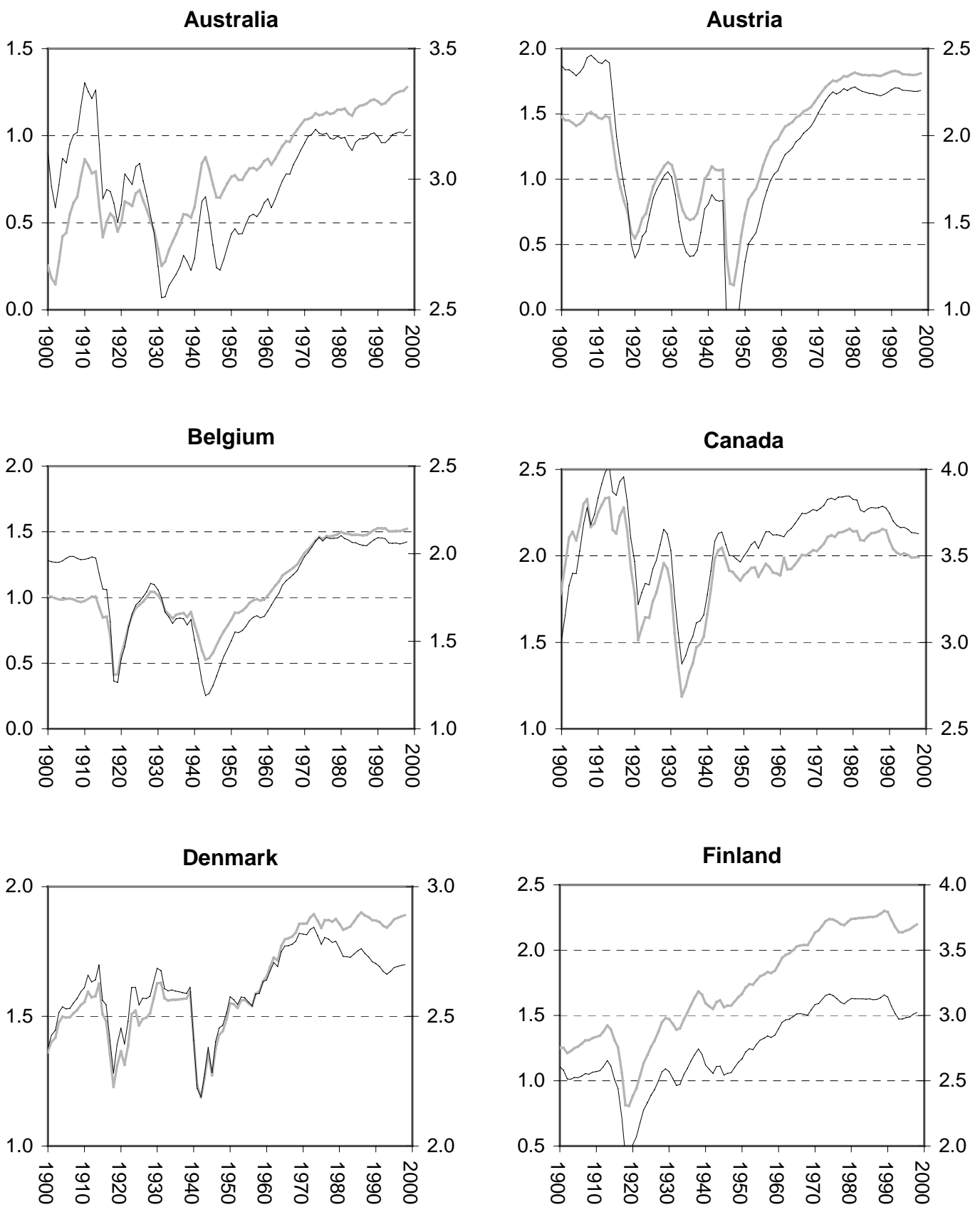
Figure 1. Trend growth rates of GDP per capita (light line, left axis) and GDP (dark line, right axis), estimated with a Kalman filter (cont'd.)
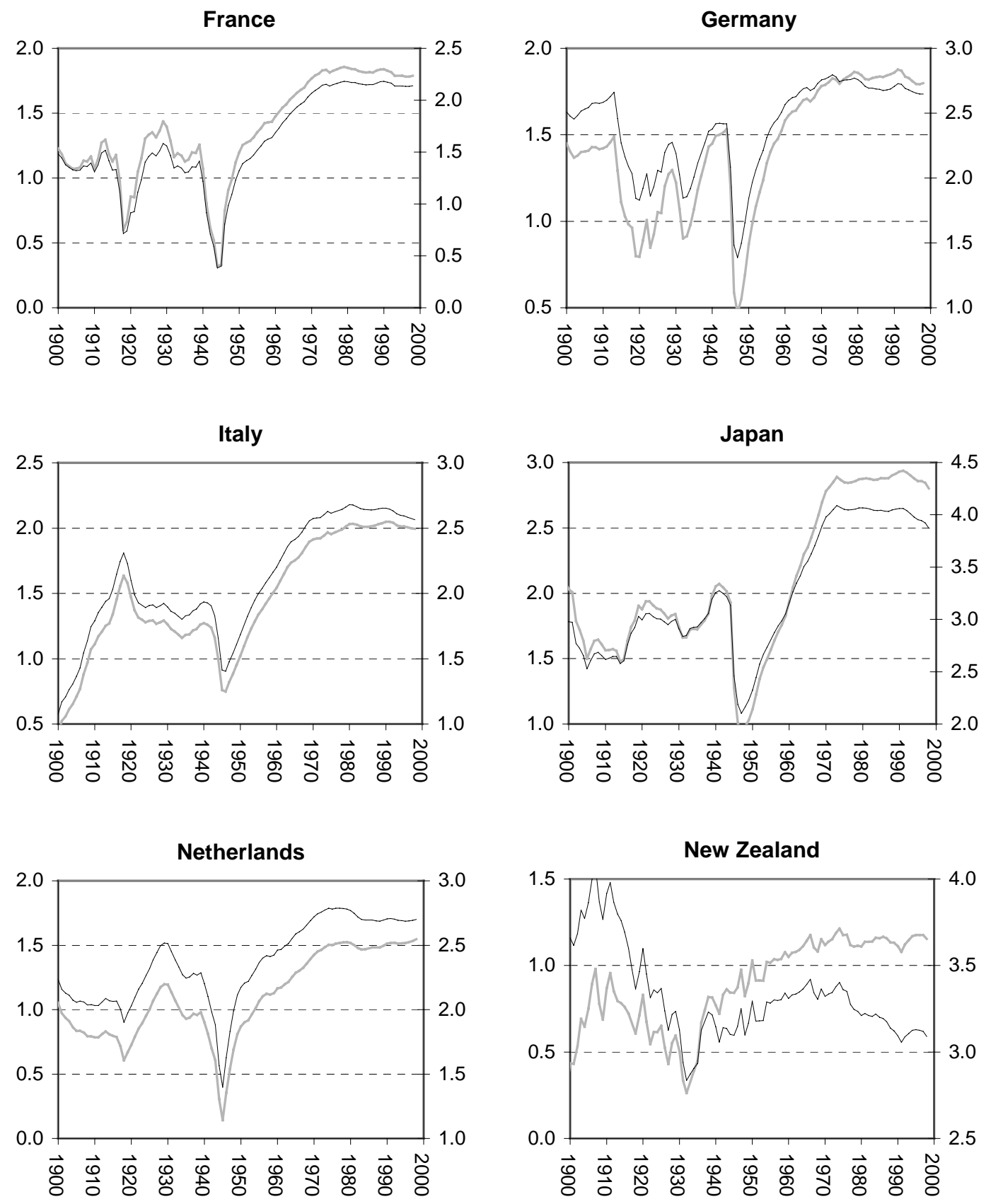
Figure 1. Trend growth rates of GDP per capita (light line, left axis) and GDP (dark line, right axis), estimated with a Kalman filter (cont'd.)
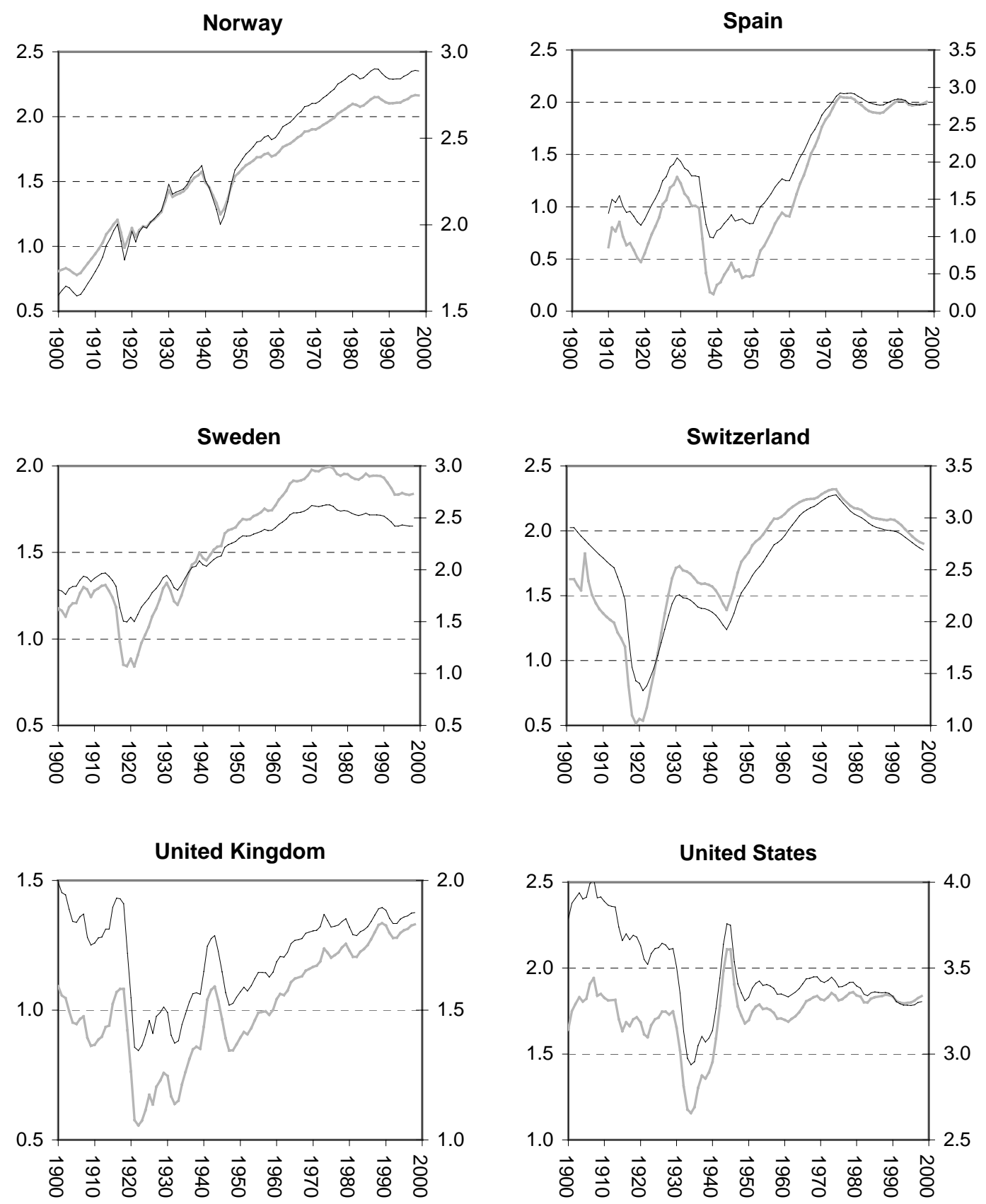


\section{Innovation and diffusion, convergence and divergence}

At a macroeconomic level, the population dynamics perspective that evolutionary economics suggests links up naturally to the debate on convergence and divergence. Part of the empirical facts of this debate is by now well established, such as the strong tendency for convergence that the OECD countries experienced during the period from 1950 to the mid-1970s. However, in order to set the agenda on what must be explained in terms of "macroeconomic population dynamics", these facts will be summarised here again, with an emphasis on the most recent period.

Figure 2 gives, for the same countries as in Figure 1, the long-run trends of convergence. Two different indicators of differences across countries are used. The first is one that has been used often in the convergence-divergence debate. It is defined as the standard deviation of the log of GDP per capita in the sample of countries. This is the dark line in Figure 2. A falling standard deviation points to convergence (country differences diminish over time). This measure essentially compares a country's GDP per capita to the (unweighted) sample average.

The figure shows that there was no or little convergence over the period 1870-1913. After this, a weak convergence trend sets in until the outbreak of World War II. This event drastically increases the heterogeneity in the sample. From the late 1940s onwards, a very strong convergence process sets in. Around 1960, the level of the indicator is back to where it was before the war, but convergence continues. In the mid-1970s, when trend growth starts to slow down in most of the countries shown in Figure 1, convergence also comes to a halt. For about a decade, per capita income differences remain stable, although from the mid-1980s, a weak convergence trend sets in again.

The light line in Figure 2 gives a different convergence indicator. This indicator is defined as the mean of the log difference of per capita income in a country relative to the most advanced country in the sample. Australia, the United Kingdom, Switzerland, Germany and the United States appear as countries with the highest value of per capita GDP in one or more years. During the post-World War II period, the United States led for most of the time. This includes the most recent period (from 1983 onwards). Abramovitz and David (1996) suggest that this indicator fits the idea of catching-up as a result of technology diffusion relatively well. The reason for this is that technology diffuses from the relatively advanced countries to the more backward countries, and this suggests comparing a country to the productivity frontier rather than to the sample average.

For the post-war convergence boom and the slowdown of convergence in the mid-1970s, the two indicators match relatively well. However, for the earliest period, the second indicator points to more convergence than the first one, and the opposite is true for the period from the start of the $20^{\text {th }}$ century to 1920.

Of most immediate interest, however, is the strong divergence of the two indicators in the most recent period. While the first indicator, which measures convergence relative to the sample mean, shows weak convergence from 1990 onwards, the second indicator, measuring convergence relative to the leader in terms of GDP per capita (i.e. the United States), shows relatively strong divergence. In other words, while the United States seems to move ahead of the other countries on average, this does not imply that these other countries are not converging towards each other.

Figure 3 enlarges the most recent period (after World War II), and also adds two more countries for which only post-war data are available (Portugal and Ireland). 
Figure 2. Long-run trends of convergence and divergence

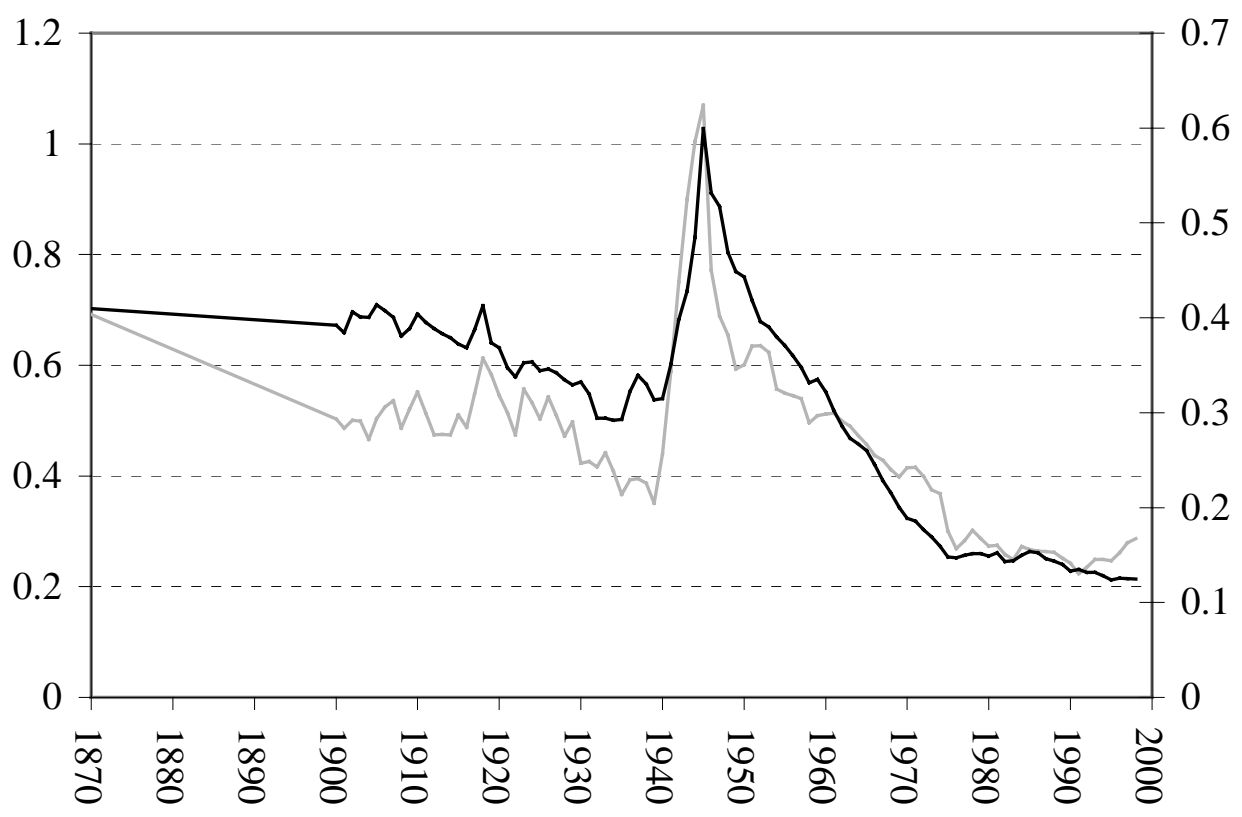

Figure 3. Convergence and divergence after World War II

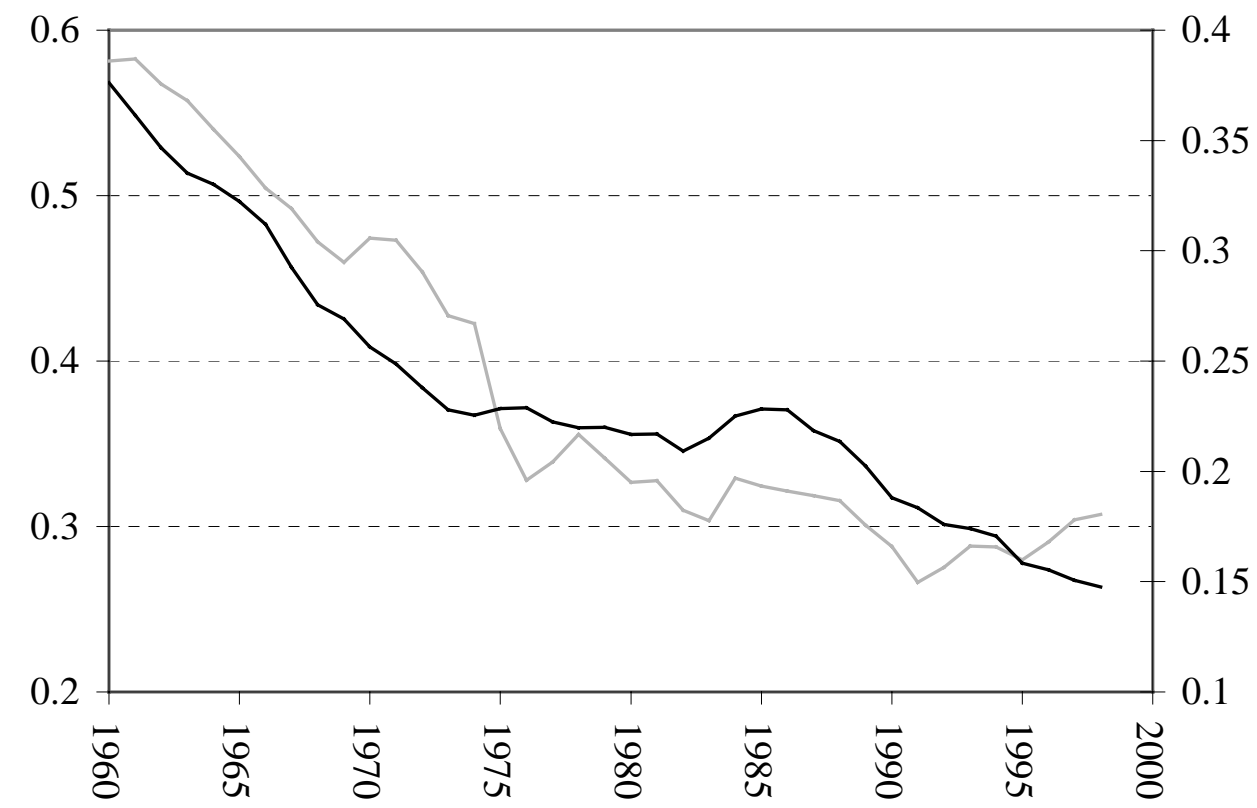


What is the interpretation of these dynamics? I will take part of the second conclusion of Section 2 and try to sketch a stylised interpretation. For that purpose, I will use and re-estimate a model developed by Fagerberg (1988b) (see also Kortum, 1997, for a somewhat similar model). Fagerberg, building on Pavitt and Soete (1982), makes the distinction between the development of new knowledge (in a country) and the diffusion of knowledge (across countries) that was also made in the second conclusion of Section 2. In an attempt to quantify these two sources of knowledge, Fagerberg regresses the level of GDP per capita on two different technology indicators: external patents per dollar of exports, and total R\&D expenditures as a fraction of GDP. His hypothesis is that this relation is log-linear rather than linear, because countries closer to the technological frontier depend more on the development of new knowledge than on diffusion. In particular, patents should be considered as an indicator of the development of new knowledge, while a part of R\&D will generally be related to assimilating foreign technology. Thus, countries with high values of GDP per capita are expected to have relatively higher values of patenting per dollar of exports, while this relationship may be somewhat less steep for R\&D.

Fagerberg's regressions were undertaken for the period 1973-83. Tables 1 and 2 repeat the regressions for this period, and extend the time coverage to an earlier period (1966-72) as well as to two more recent periods (1984-95 as a whole, and 1990-95 separately). Although an attempt was made to exactly replicate Fagerberg's results, some of his data were not available for the present exercise, and I had to resort to slightly different measures. In particular, while Fagerberg's data on patents refer to total external patents (patents by the country's residents in foreign countries), I did not have access to these data for the nonOECD countries. Therefore, I used data on patenting in the United States. ${ }^{7}$ Also, I did not have access to the data on non-military R\&D used by Fagerberg. I therefore used total R\&D (including non-business financed/performed R\&D). I use 29 countries, including Hong Kong (China), Malaysia, Philippines, Singapore, South Korea, Chinese Taipei, Thailand and Turkey in addition to the countries covered so far. ${ }^{8}$

Table 1 shows the relationship between GDP per capita and patenting per billion dollars of exports (EPA). In addition to the adjusted $\mathrm{R}^{2}$, three additional statistics are given as (indirect) tests of the nonlinearity assumption. ${ }^{9}$ The first of these (LM het.) is a Lagrange multiplier test for heteroscedasticity of the residuals. The second (JB test) is a Jarcque-Bera test for normality of the residuals. The final test (RESET test) is a Ramsey RESET test for the specification used.

The table generally points to the outcome that the log-linear specification is better than the linear specification, as expected. For example, the RESET test for the two early periods rejects the null hypothesis of correct specification for the linear variant, while it does not reject the same hypothesis for the $\log$-linear form. Also, for the linear equations 3, 5 and 6, homoscedasticity is rejected, while this is not the case for the log-linear counterparts 4, 6 and 8. For the period of Fagerberg's estimations, I find a coefficient of 2.7 on $\ln (\mathrm{EPA})$, whereas Fagerberg finds a value of 2.14 . The two values are slightly off, and the fact that the present value is slightly higher may be explained either by the different sample or by the fact that I am using US patents instead of total external patents. 
Table 1. The relation between GDP per capita and patenting activity

\begin{tabular}{|c|c|c|c|c|c|c|c|c|}
\hline & const. & EPA & $\ln (\mathrm{EPA})$ & adj. $R^{2}$ & LM het. & JB test & RESET test & $n$ \\
\hline \multicolumn{9}{|c|}{$1966-72$} \\
\hline 1 & $\begin{array}{l}0.209 \\
(0.00)\end{array}$ & $\begin{array}{l}5.721 \\
(0.00)\end{array}$ & & 0.51 & $\begin{array}{c}0.87 \\
(0.35)\end{array}$ & $\begin{array}{c}1.54 \\
(0.46)\end{array}$ & $\begin{array}{c}6.28 \\
(0.02)\end{array}$ & 28 \\
\hline 2 & $\begin{array}{l}5.098 \\
(0.00) \\
\end{array}$ & & $\begin{array}{l}2.060 \\
(0.00)\end{array}$ & 0.75 & $\begin{array}{c}0.24 \\
(0.62) \\
\end{array}$ & $\begin{array}{c}0.45 \\
(0.80)\end{array}$ & $\begin{array}{c}1.39 \\
(0.25) \\
\end{array}$ & 27 \\
\hline \multicolumn{9}{|c|}{ 1973-83 } \\
\hline 3 & $\begin{array}{l}7.475 \\
(0.00)\end{array}$ & $\begin{array}{l}0.361 \\
(0.00)\end{array}$ & & 0.53 & $\begin{array}{c}3.78 \\
(0.05)\end{array}$ & $\begin{array}{c}1.14 \\
(0.57)\end{array}$ & $\begin{array}{c}8.08 \\
(0.01)\end{array}$ & 28 \\
\hline 4 & $\begin{array}{l}6.903 \\
(0.00)\end{array}$ & & $\begin{array}{l}2.716 \\
(0.00)\end{array}$ & 0.80 & $\begin{array}{c}0.98 \\
(0.32)\end{array}$ & $\begin{array}{c}1.96 \\
(0.38)\end{array}$ & $\begin{array}{l}0.015 \\
(0.90)\end{array}$ & 28 \\
\hline \multicolumn{9}{|c|}{$1984-95$} \\
\hline 5 & $\begin{array}{c}10.265 \\
(0.00)\end{array}$ & $\begin{array}{l}0.503 \\
(0.00)\end{array}$ & & 0.44 & $\begin{array}{c}4.79 \\
(0.03)\end{array}$ & $\begin{array}{c}0.83 \\
(0.66)\end{array}$ & $\begin{array}{c}2.53 \\
(0.12)\end{array}$ & 29 \\
\hline 6 & $\begin{array}{c}11.002 \\
(0.00)\end{array}$ & & $\begin{array}{l}2.460 \\
(0.00)\end{array}$ & 0.61 & $\begin{array}{c}2.58 \\
(0.11)\end{array}$ & $\begin{array}{c}0.27 \\
(0.88)\end{array}$ & $\begin{array}{c}0.08 \\
(0.79)\end{array}$ & 29 \\
\hline \multicolumn{9}{|c|}{$1990-95$} \\
\hline 7 & $\begin{array}{c}11.404 \\
(0.00)\end{array}$ & $\begin{array}{l}0.498 \\
(0.00)\end{array}$ & & 0.35 & $\begin{array}{c}4.45 \\
(0.04)\end{array}$ & $\begin{array}{c}1.41 \\
(0.49)\end{array}$ & $\begin{array}{c}1.51 \\
(0.23)\end{array}$ & 29 \\
\hline 8 & $\begin{array}{c}12.229 \\
(0.00)\end{array}$ & & $\begin{array}{r}2.315 \\
(0.00) \\
\end{array}$ & 0.55 & $\begin{array}{c}1.88 \\
(0.17) \\
\end{array}$ & $\begin{array}{c}0.63 \\
(0.73)\end{array}$ & $\begin{array}{c}1.07 \\
(0.31) \\
\end{array}$ & 29 \\
\hline
\end{tabular}

Note: GDP per capita is always in levels, not logs; $p$-values of a two-sided $t$-test between brackets.

Table 2. The relation between GDP per capita and R\&D intensity (total R\&D)

\begin{tabular}{|c|c|c|c|c|c|c|c|c|}
\hline & const. & $\mathrm{RD}$ & $\ln (\mathrm{RD})$ & adj. $R^{2}$ & LM het. & JB test & RESET test & $\mathrm{n}$ \\
\hline \multicolumn{9}{|c|}{$1966-72$} \\
\hline 1 & $\begin{array}{l}6.255 \\
(0.00)\end{array}$ & $\begin{array}{l}3.015 \\
(0.00)\end{array}$ & & 0.58 & $\begin{array}{c}0.69 \\
(0.41)\end{array}$ & $\begin{array}{c}0.53 \\
(0.77)\end{array}$ & $\begin{array}{c}0.00 \\
(0.98)\end{array}$ & 16 \\
\hline 2 & $\begin{array}{l}9.899 \\
(0.00)\end{array}$ & & $\begin{array}{l}2.692 \\
(0.00)\end{array}$ & 0.55 & $\begin{array}{c}1.06 \\
(0.30)\end{array}$ & $\begin{array}{c}0.70 \\
(0.70)\end{array}$ & $\begin{array}{c}0.84 \\
(0.38)\end{array}$ & 16 \\
\hline \multicolumn{9}{|c|}{ 1973-83 } \\
\hline 3 & $\begin{array}{l}8.637 \\
(0.00)\end{array}$ & $\begin{array}{l}3.228 \\
(0.00)\end{array}$ & & 0.58 & $\begin{array}{c}0.06 \\
(0.81)\end{array}$ & $\begin{array}{c}0.45 \\
(0.80)\end{array}$ & $\begin{array}{c}1.42 \\
(0.25)\end{array}$ & 19 \\
\hline 4 & $\begin{array}{c}12.366 \\
(0.00) \\
\end{array}$ & & $\begin{array}{c}3.79 \\
(0.00) \\
\end{array}$ & 0.64 & $\begin{array}{c}0.33 \\
(0.56) \\
\end{array}$ & $\begin{array}{c}0.31 \\
(0.85) \\
\end{array}$ & $\begin{array}{c}0.00 \\
(0.98)\end{array}$ & 19 \\
\hline \multicolumn{9}{|c|}{$1984-95$} \\
\hline 5 & $\begin{array}{l}7.449 \\
(0.00)\end{array}$ & $\begin{array}{l}4.319 \\
(0.00)\end{array}$ & & 0.58 & $\begin{array}{c}0.21 \\
(0.64)\end{array}$ & $\begin{array}{c}1.89 \\
(0.39)\end{array}$ & $\begin{array}{c}5.53 \\
(0.03)\end{array}$ & 27 \\
\hline 6 & $\begin{array}{c}12.970 \\
(0.00)\end{array}$ & & $\begin{array}{l}5.135 \\
(0.00)\end{array}$ & 0.67 & $\begin{array}{c}0.09 \\
(0.76)\end{array}$ & $\begin{array}{c}9.01 \\
(0.01)\end{array}$ & $\begin{array}{c}0.00 \\
(0.95)\end{array}$ & 27 \\
\hline $6 a$ & $\begin{array}{c}13.944 \\
(0.00) \\
\end{array}$ & & $\begin{array}{l}4.877 \\
(0.00)\end{array}$ & 0.66 & $\begin{array}{c}0.75 \\
(0.39)\end{array}$ & $\begin{array}{c}0.59 \\
(0.74)\end{array}$ & $\begin{array}{c}0.94 \\
(0.35)\end{array}$ & 19 \\
\hline \multicolumn{9}{|c|}{$1990-95$} \\
\hline 7 & $\begin{array}{l}8.205 \\
(0.00)\end{array}$ & $\begin{array}{l}4.181 \\
(0.00)\end{array}$ & & 0.55 & $\begin{array}{c}0.02 \\
(0.89)\end{array}$ & $\begin{array}{c}2.82 \\
(0.24)\end{array}$ & $\begin{array}{c}9.06 \\
(0.01)\end{array}$ & 27 \\
\hline 8 & $\begin{array}{c}13.464 \\
(0.00)\end{array}$ & & $\begin{array}{l}5.263 \\
(0.00)\end{array}$ & 0.69 & $\begin{array}{c}0.50 \\
(0.48)\end{array}$ & $\begin{array}{c}7.88 \\
(0.02)\end{array}$ & $\begin{array}{c}0.09 \\
(0.77)\end{array}$ & 27 \\
\hline $8 a$ & $\begin{array}{l}14.412 \\
(0.00)\end{array}$ & & $\begin{array}{l}4.996 \\
(0.00)\end{array}$ & 0.63 & $\begin{array}{c}2.33 \\
(0.13)\end{array}$ & $\begin{array}{c}0.98 \\
(0.61)\end{array}$ & $\begin{array}{c}1.54 \\
(0.23)\end{array}$ & 19 \\
\hline
\end{tabular}

Note: GDP per capita is always in levels, not logs; $p$-values of a two-sided $t$-test between brackets. 
The values on $\ln (\mathrm{EPA})$ differ somewhat for the other periods. Post-1983 lower values are obtained, with almost no difference between the period 1984-95 as a whole and the last six years of this period. However, the difference compared to the 1973-83 period is only small. For 1966-73, the value is also smaller compared to Fagerberg's period.

Table 2 gives the same regressions for R\&D intensity (RD). Here again the specification tests generally point to the log-linear form as a better approximation of the true relationship, especially so for the period since 1984 (RESET test). There is one crucial difference with Table 1, however, and that is the fact that the coefficient on $\ln (\mathrm{RD})$ is rising strongly and monotonically over time. Because the sample size also grows over time (especially as the Asian countries do not have R\&D for the two early periods), equations $6 \mathrm{a}$ and $8 \mathrm{a}$ repeat, respectively, equations 6 and 8 for the same sample of countries as in equation 4 . The results show that, although part of the rise of the coefficient is due to the larger sample, this does not explain the largest part of the rise.

What the results show then, is that for given levels of R\&D intensity, it is easier to attain a (relative) level of GDP per capita in the recent period than it was in the early period. This also holds to a much lesser extent for patenting. Although the argument is admittedly somewhat speculative, I suggest that this result is a good illustration of the nature of the economic growth as a process of transformation that was argued above to be typical for evolutionary economics. In the early period, R\&D and patents could be viewed more or less as different indicators of the same process of technology accumulation. Then, with the process of technological catching-up of the relatively backward nations, R\&D became a process that, in some countries, is increasingly aimed at imitating foreign technology. This is why high R\&D intensities now also start to arise at relatively low levels of development. Patenting, on the other hand, remains an indicator of innovation rather than assimilation of diffused knowledge, and hence the value of the coefficient on this variable does not decline so much. What this shows is that catching-up by assimilating foreign technology becomes a more active process, at least in terms of $\mathrm{R} \& \mathrm{D}$, while the ultimate technological frontier remains a matter for (a handful of) highly developed countries.

Table 3 re-estimates the dynamic specification of Fagerberg's growth model. The dependent variable is the average annual compound growth rate of GDP. The basic point about the model is the distinction between innovation as a source of divergence and diffusion as a source of convergence that was made above. Hence the two crucial factors in the model are innovation (as indicated by either patents or R\&D), and catch-up potential (as indicated as GDP per capita). The patent variable is specified as the average annual growth rate of the number of patents in the United States, $R \& D$ as the average annual growth rate of real R\&D expenditures..$^{10}$ Investment (as a fraction of GDP, average over the period indicated) and the growth rate of real exports (annual compound growth rate) are included as two factors influencing the realisation of catch-up potential.

The model is specified with slope dummies with 1984-95 as the base period. In columns (1), (2) and (3), the effects for the other periods are specified as changes to the base period. Significant $p$-values in these columns point to significant deviations from the coefficient values in the base period 1984-95. Columns (1a), (2a) and (3a) can be derived by adding up the base period effect and the change to this for the current period (both shown in the previous column). The $p$-values given here are for tests on the joint significance of the two coefficients, i.e. for the significance of the variable in question for the period under consideration. 
Table 3. Estimation results for Fagerberg's growth model

\begin{tabular}{|c|c|c|c|c|c|c|}
\hline & 1 & $1 a$ & 2 & $2 a$ & 3 & $3 a$ \\
\hline $\begin{array}{r}\text { constant } \\
\text { c 84-95 }\end{array}$ & $\begin{array}{l}0.024 \\
(0.12)\end{array}$ & & $\begin{array}{l}0.004 \\
(0.83)\end{array}$ & & $\begin{array}{l}0.038 \\
(0.00)\end{array}$ & \\
\hline $\begin{array}{l}(\Delta) \text { с 73-83 } \\
(\Delta) \subset 66-72\end{array}$ & $\begin{array}{l}0.019 \\
(0.40) \\
0.030 \\
(0.22) \\
\end{array}$ & $\begin{array}{l}0.043 \\
(0.01) \\
0.054 \\
(0.00) \\
\end{array}$ & $\begin{array}{l}0.052 \\
(0.03) \\
0.051 \\
(0.04) \\
\end{array}$ & $\begin{array}{l}0.056 \\
(0.00) \\
0.055 \\
(0.00) \\
\end{array}$ & $\begin{array}{l}-0.007 \\
(0.56) \\
0.011 \\
(0.59) \\
\end{array}$ & $\begin{array}{l}0.031 \\
(0.00) \\
0.049 \\
(0.01) \\
\end{array}$ \\
\hline $\begin{array}{l}\text { patents } \\
\text { p 84-95 }\end{array}$ & 0.162 & & 0.142 & & 0.164 & \\
\hline $\begin{array}{l}(\Delta) \mathrm{p} 73-83 \\
(\Delta) \mathrm{p} \mathrm{66-72}\end{array}$ & $\begin{array}{l}-0.118 \\
(0.00) \\
-0.177 \\
(0.03) \\
\end{array}$ & $\begin{array}{l}0.044 \\
(0.02) \\
-0.015 \\
(0.85) \\
\end{array}$ & $\begin{array}{l}-0.080 \\
(0.01) \\
-0.167 \\
(0.04) \\
\end{array}$ & $\begin{array}{l}0.062 \\
(0.00) \\
-0.025 \\
(0.74) \\
\end{array}$ & $\begin{array}{l}-0.165 \\
(0.00) \\
-0.058 \\
(0.54) \\
\end{array}$ & $\begin{array}{l}-0.001 \\
(0.25) \\
0.106 \\
(0.25)\end{array}$ \\
\hline $\begin{array}{r}\text { investment } \\
\text { i 84-95 }\end{array}$ & $\begin{array}{l}0.064 \\
(0.22)\end{array}$ & & $\begin{array}{l}0.090 \\
(0.03)\end{array}$ & & & \\
\hline $\begin{array}{l}(\Delta) \text { i } 73-83 \\
(\Delta) \text { i } 66-72\end{array}$ & $\begin{array}{l}0.034 \\
(0.68) \\
0.087 \\
(0.36) \\
\end{array}$ & $\begin{array}{l}0.098 \\
(0.12) \\
0.151 \\
(0.06) \\
\end{array}$ & $\begin{array}{l}-0.059 \\
(0.40) \\
0.056 \\
(0.51) \\
\end{array}$ & $\begin{array}{l}0.031 \\
(0.57) \\
0.146 \\
(0.05) \\
\end{array}$ & & \\
\hline $\begin{array}{c}\text { catch-up po } \\
\text { t 84-95 }\end{array}$ & $\begin{array}{l}\text { ntial } \\
-0.114 \\
(0.08)\end{array}$ & & $\begin{array}{l}-0.086 \\
(0.10)\end{array}$ & & $\begin{array}{l}-0.142 \\
(0.00)\end{array}$ & \\
\hline $\begin{array}{l}(\Delta) \text { t 73-83 } \\
(\Delta) \text { t 66-72 }\end{array}$ & $\begin{array}{l}-0.226 \\
(0.01) \\
-0.305 \\
(0.02)\end{array}$ & $\begin{array}{l}-0.340 \\
(0.00) \\
-0.419 \\
(0.00) \\
\end{array}$ & $\begin{array}{l}-0.213 \\
(0.01) \\
-0.339 \\
(0.01)\end{array}$ & $\begin{array}{l}-0.299 \\
(0.00) \\
-0.425 \\
(0.00) \\
\end{array}$ & $\begin{array}{l}0.030 \\
(0.70) \\
0.014 \\
(0.91) \\
\end{array}$ & $\begin{array}{l}-0.112 \\
(0.12) \\
-0.128 \\
(0.31)\end{array}$ \\
\hline $\begin{array}{l}\text { exports } \\
\text { e } 84-95\end{array}$ & & & $\begin{array}{l}0.342 \\
(0.00)\end{array}$ & & $\begin{array}{l}0.155 \\
(0.08)\end{array}$ & \\
\hline$(\Delta)$ e $73-83$ & & & $\begin{array}{l}-0.385 \\
(0.11)\end{array}$ & $\begin{array}{l}-0.043 \\
(0.84)\end{array}$ & $\begin{array}{l}-0.239 \\
(0.16)\end{array}$ & $\begin{array}{l}-0.084 \\
(0.57)\end{array}$ \\
\hline$(\Delta)$ e $66-72$ & & & $\begin{array}{l}-0.291 \\
(0.02)\end{array}$ & $\begin{array}{l}0.051 \\
(0.34)\end{array}$ & $\begin{array}{l}-0.120 \\
(0.45)\end{array}$ & $\begin{array}{l}0.034 \\
(0.80)\end{array}$ \\
\hline $\begin{array}{r}\text { R\&D } \\
r \text { 84-95 }\end{array}$ & & & & & $\begin{array}{l}0.010 \\
(0.56)\end{array}$ & \\
\hline$(\Delta)$ r 73-83 & & & & & $\begin{array}{l}0.175 \\
(0.05)\end{array}$ & $\begin{array}{l}0.185 \\
(0.03)\end{array}$ \\
\hline$(\Delta)$ r 66-72 & & & & & $\begin{array}{l}0.053 \\
(0.56)\end{array}$ & $\begin{array}{l}0.063 \\
(0.49)\end{array}$ \\
\hline $\begin{array}{r}\operatorname{adj} . R^{2} \\
n\end{array}$ & $\begin{array}{c}0.66 \\
80\end{array}$ & & $\begin{array}{c}0.68 \\
79\end{array}$ & & $\begin{array}{c}0.84 \\
63\end{array}$ & \\
\hline
\end{tabular}

Note: $p$-values of a two-sided $t$-test between brackets.

The results generally support the two sides of technological changes. The significantly negative signs on the GDP per capita variable (rows with coefficients $t$ ) show the relevance of the diffusion argument. However, for specification (1)/(1a), which is the most basic variant of the model, the strength of this relationship diminishes over time (this trend also seemed to surface already in the original Fagerberg, 1987 estimations). This also holds for specification (2)/(2a), which adds export growth to the explanatory variables. It does not hold, however, for specification (3)/(3a), which includes $R \& D$ as a technology variable alongside patents. Hence, in general, the results seem to indicate that for the present sample of countries, catching-up becomes a less and less easy way of growing rapidly. R\&D may well interact with 
catching-up, as suggested in the comments to Tables 1 and 2 above, as indicated by the different results between models (1) and (2), on the one hand, and model (3), on the other hand.

In model (1)/(1a), patenting (rows with coefficient $\mathrm{p}$ ) is significant in the two last periods (with a much higher coefficient in the very last period), but not in the early period. Thus, when catching up (i.e. relying on diffusion) seems to become less and less easy, "pure" innovation seems to become more and more important. Model (2) confirms this result. In model (3), patenting is only significant for the most recent period, while R\&D (rows with coefficient r) is only significant for the period 1973-83.

Investment (rows with coefficient i) is not significant in model (1), but it becomes significant in the most recent period when exports (rows with coefficient e) are included, as in model (2). The exports variable is also only significant in the recent period.

Two conclusions emerge from these estimations. First, the relative importance of diffusion (leading to convergence) and innovation (leading to divergence) differs between sub-periods of the time span 1966-95. The slowdown of convergence since the mid-1970s seems to be related both to an increase of the elasticity of economic growth with respect to technology (patents), and to a decrease of catch-up potential. The second conclusion is that catching-up (assimilating technology diffusion) may have become harder over the period. There are indications that $\mathrm{R} \& \mathrm{D}$ is now an important aspect of assimilating international technology diffusion, rather than a "direct" source of growth. ${ }^{11}$ This links up naturally to the conclusions derived on economic growth as a transformation process from the above "static" estimations.

\section{Structural change and technology}

That radical innovation leads to structural change and economic growth is a central hypothesis in many evolutionary perspectives on the relation between technology and growth (see, for example, Freeman and Soete, 1990). Obviously, the so-called information and communication technologies (ICT) are a potential example of such a radical innovation in the current economy. Although the technology (in the form of computers) was pioneered in the Second World War, its huge potential only became fully obvious with two events which took place in the 1980s. The first of these was the miniaturisation resulting from a number of important innovations in the semiconductor industry (first the transistor, then the integrated circuit, and finally the microchip). This led to small, cheap computers that could be afforded by large numbers of users. The second event was the linking of computers in networks, and the linking of these networks by existing telecommunication technologies (telephones). ${ }^{12}$

It is now generally recognised that ICT is a radical innovation that unlocks important growth potential for the world economy (OECD, 2000), as did other major innovations in the past (see, for example, Freeman and Soete, 1997, for an historical account of other basic innovations and their impact on economic growth). However, in the 1980s and early 1990s, mainstream economics was occupied with Solow's paradox, which states that "we see computers everywhere except in the statistics on productivity growth". In other words, what Solow seemed to be pointing to was relatively rapid structural change, with no associated effect on growth. Contributions to the literature that I would characterise as evolutionary (most importantly, Freeman and Soete, 1990, and David, 1990) seemed to be much less surprised by the lack of a direct relationship, and pointed to a time lag between the two events.

The recent discussion, indeed, seems to point to the fact that productivity growth has been positively influenced by ICT [probably one of the earliest contributions pointing to such an effect is Van Meijl (1995), a more recent contribution is Ten Raa and Wolff (1999); OECD (2000) discusses recent theoretical evidence for a large set of countries]. However, a new paradox seems to emerge from these discussions (see also Fagerberg, 2000). Now the issue is the apparent contrast between the small share of ICT equipment in total investment and the large productivity increases that are associated with this. More 
specifically, calculations show that the ICT content of the total capital stock must be relatively small due to two factors: the rapid rate of depreciation of ICT equipment (computers typically have a life span of two to three years at most, versus more than ten years for most other machinery), and the small share of ICT equipment in total investment expenditures. Applying a traditional growth accounting methodology (which uses factor shares as weights to calculate contributions of sectors to growth) would tend to conclude that the impact of ICT on overall growth is small (see, for example, Oliner and Sichel, 1994).

However, using the most recent data available for the United States, which is probably the most researched country with respect to this paradox, one must conclude that the ICT share in total investment has grown rapidly over the 1990s (see also OECD, 2000). I used input-output tables for the United States to illustrate the argument. ${ }^{13}$ The tables contain 71 commodities, among which I classified five as ICT commodities. Three of these five are manufactured goods (hardware): "Computer and office equipment", "Audio, video and communication equipment", and "Electronic components and accessories". The two services groups defined as ICT are "Communications, except radio and TV" and "Computer and data processing services".

Table 4. The share of ICT goods in gross private fixed investment, United States, 1992 and 1996, current prices

\begin{tabular}{lcc}
\hline \multicolumn{1}{c}{ Commodity group } & 1992 & 1996 \\
& $\begin{array}{c}\text { Share Inv } \\
\text { direct (\%) }\end{array}$ & $\begin{array}{c}\text { Share Inv } \\
\text { direct (\%) }\end{array}$ \\
\hline Computer and office equipment & 4.6 & 4.8 \\
Audio, video and communication equipment & 3.1 & 3.4 \\
Electronic components and accessories & 0.0 & 0.0 \\
Communications, except radio and TV & 0.6 & 8.1 \\
Computer and data processing services & 0.4 & 16.8 \\
\hline Total ICT commodities & 8.7 & \\
\hline
\end{tabular}

Source: Calculations on the Bureau of Economic Analysis input-output tables.

Table 4 shows how the share of ICT in investment is nearly doubled over the time span of four years. Nearly $9 \%$ of total investment expenditures goes to ICT in 1992, versus $16.8 \%$ in 1996. This increase results almost completely from an increase in the services part of ICT, which is a phenomenon that has, for example, attracted attention from Petit and Soete (2000). Note that these results probably even understate the growth in real terms, because prices for ICT equipment have generally been falling, especially when quality adjustment are taken into account (see, for example, Triplett, 1996). Especially computer and data processing services were responsible for this rapid increase. The share of this group increased twenty-fold. The rapid growth of ICT inputs in investment over the recent period seems to be in line with the argument by David (1990) that new radical technologies diffuse slowly. David also shows that the productivity gains associated with this diffusion generally lag behind the diffusion itself.

Naturally, the increased demand for ICT goods (as illustrated for investment demand in the above table) has led to a strong increase of the share of this sector in value added or gross production. An important element of the total demand for "pervasive" technologies is associated with "indirect" demand, i.e. derived demand from intermediary use. For example, both neo-classical (e.g. Katsoulacos, 1986) and 
evolutionary-oriented (e.g. Freeman and Soete, 1987) suggest that such indirect effects are important for generating new employment as a result of technological change. How strong is this effect for ICT goods?

In order to answer this question, I apply a decomposition technique suggested by Los (1999). The technique decomposes the growth rate of (gross) production in a commodity group into three different effects. The first is the growth rate of overall final demand. This effect is similar for all commodity groups, and hence I leave it out of my calculations. The second effect is related to changes in the composition of final demand. Continuing the focus on ICT as an investment good, I have used the composition of final private investment, i.e. the shares of commodity groups in the total investment demand. This effect measures the impact of decisions by firms to substitute non-ICT goods for ICT goods in their total investment bundle. An example would be to start using computers instead of typewriters. The final effect is related to changes in the matrix describing intermediate demand (the so-called inverse Leontief matrix). This effect measures changes in the embodiment of ICT goods in non-ICT investment goods (e.g. numerically controlled lathes, electronics in cars). ${ }^{15}$

The results are shown in Table 5. The first column (Qratio) gives the growth of gross production incurred for total investment, i.e. the sum of direct and indirect effects. Numbers between brackets show the ranking. As could be expected from Table 4, some of the ICT commodity groups rank high. Computer services is the group with the highest growth rate, while electronic components ranks third. The second column shows the effect that is related to changes in the composition of investment demand (the "direct" effect of, for example, using typewriters instead of computers). The third column shows the indirect effect (associated with changes in intermediate demand, or "technical coefficients", e.g. embodying electronics in other investment goods). What is interesting is that most of the ICT commodity groups, with the exception of electronic components (and to a lesser extent communications), have large direct effects, but relatively low indirect effects (higher ranks in the second column than in the third column).

The column labelled "Share Inv total" gives the share of ICT commodity groups in total costs incurred for investment. This column can be compared to Table 4 to see that for ICT as whole, the total effect (direct plus indirect) is somewhat smaller than the direct effect. This shows that indirect effects are not only relatively minor in a dynamic perspective, but also in a static measure. ${ }^{16}$

The table provides three additional commodity groups that are characterised by high growth of their share in total costs incurred for investment. These are included for reference. Together with the two ICT groups electronic components and computer services, these sectors comprise the top five most rapidly growing components of total investment costs. The three additional sectors are all sectors that grow from a small base (typically half a percentage point or less in total investment costs). All three of these commodity groups are in services, and they typically score high on indirect effects rather than on direct effects (although educational services scores high on both). Arguably, each of these commodity groups can be viewed as a major application area for ICT commodities, pointing to interdependencies not captured by the analysis here.

What this shows is that, although ICT is by now a major component in total investment demand in the United States, the pervasiveness of this radical innovation is limited in the sense that it does not (yet) lead to comparably high indirect production effects. Obviously, such indirect effects may lead to additional economic growth, or to growth in employment. This suggests that the existing relationship between ICT and economic growth (e.g. Ten Raa and Wolff, 1999) must be largely ascribed to externalities associated with the introduction of ICT equipment (as suggested by Van Meijl, 1995). 
DSTI/DOC(2001)1

Table 5. The importance of ICT goods in total (gross) production incurred for gross private fixed investment, United States, 1992 and 1996, current prices

\begin{tabular}{|c|c|c|c|c|c|}
\hline \multirow{2}{*}{ Commodity group } & \multirow[t]{2}{*}{ Ratio Q } & \multirow[t]{2}{*}{ Direct } & \multirow[t]{2}{*}{ Indirect } & \multicolumn{2}{|c|}{ Share Inv total (\%) } \\
\hline & & & & 1992 & 1996 \\
\hline ICT commodities & & & & 8.3 & 13.6 \\
\hline Computer and office equipment & $1.75(13)$ & $1.15(6)$ & $0.99(63)$ & $2.8(7)$ & $3.1(6)$ \\
\hline Audio, video and communication equipment & $1.66(24)$ & $1.07(13)$ & $1.01(55)$ & $1.7(16)$ & $1.8(16)$ \\
\hline Electronic components and accessories & $2.37(3)$ & $1.12(4)$ & $1.38(4)$ & $2.0(12)$ & $3.0(8)$ \\
\hline Communications (excl. radio and TV) & $1.67(18)$ & $1.00(30)$ & $1.09(12)$ & $1.0(30)$ & $1.1(27)$ \\
\hline Computer and data processing services & $8.88(1)$ & $5.98(1)$ & $0.97(68)$ & $0.8(39)$ & $4.6(4)$ \\
\hline \multicolumn{6}{|l|}{ Rapid growing investment components } \\
\hline Educational and social services & $2.55(2)$ & $1.20(3)$ & $1.38(3)$ & $0.2(77)$ & $0.1(64)$ \\
\hline Radio and TV broadcasting & $2.18(4)$ & $1.02(19)$ & $1.39(1)$ & $0.0(87)$ & $0.0(87)$ \\
\hline Insurance & $2.01(5)$ & $0.95(58)$ & $1.39(2)$ & $0.4(52)$ & $0.5(44)$ \\
\hline
\end{tabular}

Note: "RatioQ": gross production incurred for investment, 1996 value divided by 1992 value; "direct": impact of shifts in composition of final demand investment component; "indirect": impact of changes in the inverse Leontief matrix (intermediate demand). RatioQ $=$ direct $^{\star}$ indirect ${ }^{\star} 1.53$ (1.53 is the value of total investment demand in 1996 divided by the value in 1992). "Share Inv total": share in total costs incurred for investment. Numbers between brackets are ranks. Source: Calculations on the Bureau of Economic Analysis input-output tables.

\section{International Markets: Adjustment and Dynamics}

The final conclusion from the brief review of evolutionary growth theory carried out above is that dynamics of markets matter. Evolutionary economics suggests that markets do not adjust immediately to long-run equilibrium associated with the patterns of comparative advantage of countries. In line with the Schumpeterian notion of disequilibrium dynamics, the working of markets (e.g. what is important for competitiveness, low wages or technology) may change before the situation settles down in an equilibrium specialisation pattern.

The importance of this argument is obviously a complex matter that can only be settled by means of comparative model building, something that is obviously outside the scope of this paper. The analysis here is therefore limited to an illustration of the argument by means of some relatively simple empirical indicators. The starting point of the analysis is the finding in Section 4 that the relative importance of innovation as a source of divergence versus technology diffusion as a source of convergence may vary over time. In Section 4, this conclusion was reached on the basis of Fagerberg's macroeconomic growth model. This section will attempt to illustrate the model by looking at the dynamics of trade market shares.

As in Section 4, patents obtained in the United States are used as the primary indicator of technological competitiveness. The EPA indicator used there (patents per dollar of exports) is used again here, although it is modified slightly. Patents are now defined at the sectoral level (using the concordance between patent classes and US SICs provided by the US Patent and Trademark Office), and are divided yearly by exports in current dollars. Exports are exports to the OECD area ( 24 countries, excluding Korea and Mexico). ${ }^{17}$ Besides these OECD countries, a number of non-OECD countries were included in the sample for which market shares are calculated, bringing the total number of countries in the sample to 31 . $^{18}$ The total market is defined as imports into 24 OECD countries from these 31 countries (i.e. the rest of the world is ruled out).

The (modified) EPA variable is used to indicate "strategies" of countries in world markets. In order not to overly complicate the analysis, and because data for the complete set of countries are difficult to 
obtain, no additional "strategy" indicators (such as unit wage costs or productivity) are used. Implicitly, an inverse relationship between technological competitiveness and cost competitiveness will be assumed ("high technological competencies lead to high wages"). Hence, a high value for EPA is seen an indicator for a technology-based strategy, whereas a low value for this indicator is associated with competitiveness based on cost. In order to filter out trends in the value of EPA over time, the values of this indicator for each country in each year are transformed to the rank order of this variable (yielding numbers 1-31). ${ }^{19}$

For each year in the period 1970-95, the distribution of market shares in a sector can be expressed as a function of the EPA rank. High concentration of market share for high ranks of the EPA variable would indicate that the market is dominated by "players" which apply a high-tech strategy. The analysis will look at the trends of this distribution over time for different sectors. The histograms shown below have been smoothed using a so-called Epanechnikov kernel (see Härdle, 1990, for details).

Figure 4 gives the results. On the horizontal axis of the figures the rank of the EPA variable is shown. Values to the left (right) indicate a high-technology (low-technology/low-cost) strategy. The vertical axis shows time. Shading indicates market shares. Darker shading indicates higher concentration of market shares. ${ }^{20}$ The choice of the sectors is arbitrary, although not completely random. The first four sectors are sectors that have been defined as high-tech sectors, i.e. those in which a technology strategy can be assumed to be important (for the definition of high-tech used here, see OECD/EUROSTAT, 1995). The first two of these sectors (computers and office machines; radio, TV, telecom and semiconductors) are the core ICT hardware sectors used in the previous section. The two last sectors are low-tech sectors (according to the same definition).

What story do these diagrams tell about the dynamics of markets, and differences in this respect between markets? At a general level, the figures show that the relationship between technology strategies and market share is far from stable over time. Except for food, drinks and tobacco, all the figures show a clear movement of the dark bands in the market share-strategy plane.

At a more detailed level, however, it becomes clear that are no common patterns across sectors. Each sector seems to have its own dynamic pattern. Even the two sectors that are perhaps most related in economic and technological terms, i.e. the two ICT sectors at the top of the page, show quite different developments over time, and this holds even more strongly for other sectors. In the two ICT sectors, the computer sector shows the widest dispersion of market shares over technology strategies in the early 1970s. The radio, TV, telecom and semiconductors sector initially shows concentration of market shares in a band somewhat below the absolute highest level of the EPA variable (say, ranks 6 to 11). In the computer sector, concentration in the high-technology strategy area can be observed until the mid-1980s. During the same period, the radio, TV, telecom and semiconductors sector develops marginally in the direction of a higher importance of low-tech (and low-cost) strategies, with a small island arising on the right side of the figure during the first half of the 1980s. The same happens in the mid-1990s for the computer industry, while at the same time, the radio, $\mathrm{TV}$, telecom and semiconductors industry moves more in the direction of high-technology strategies.

The pharmaceuticals industry shows a similar ridge, as found in the radio, TV, telecom and semiconductors industry, just below the absolute highest values for the EPA variable. In this case, this ridge is visible for almost the complete period, with a slight movement to the right (less technologyintensive) for the most recent period. As in the computer industry (although to a lesser extent), a development in the direction of two peaks (a high-tech strategy and a low-cost strategy) seems to occur here. Instruments shows a rather flat distribution that initially seems to converge to a single high-tech peak (until the mid-1980s), and then seems to dissipate into three (low) peaks that cover nearly the full spectrum of technology strategies. 
Figure 4. Market share dynamics and technology strategies, technology strategies on horizontal axis, dark areas indicate concentration of market share

Computers and office machines (ISIC 3825)

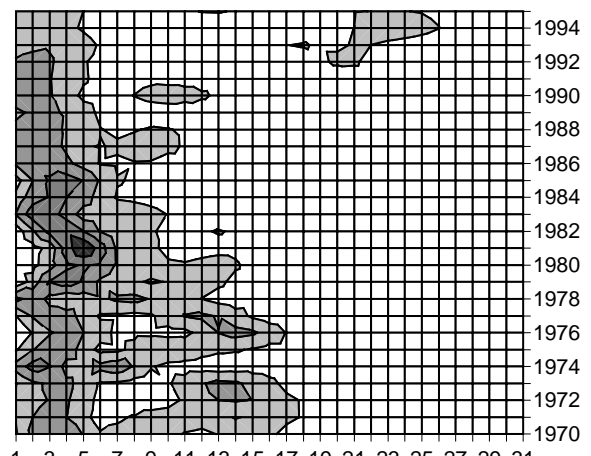

$\begin{array}{llllllllllllllllllll}1 & 3 & 5 & 7 & 9 & 11 & 13 & 15 & 17 & 19 & 21 & 23 & 25 & 27 & 29 & 31\end{array}$

$\square 0-0.04 \square 0.04-0.08 \square 0.08-0.12 \square 0.12-0.16 \square 0.16-0.2$

Pharmaceuticals (ISIC 3522)

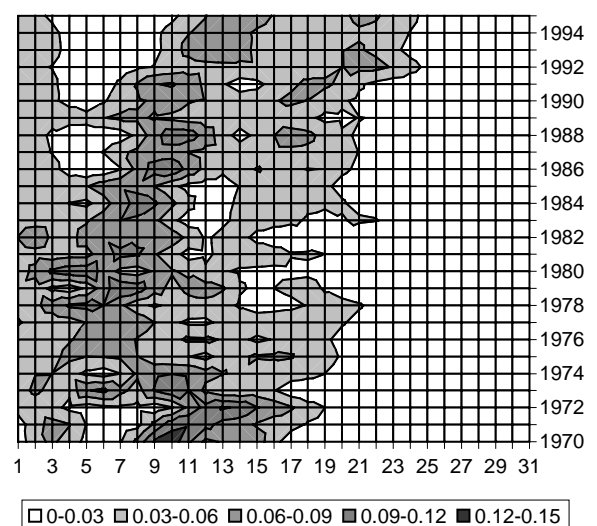

Food, drinks, tobacco (ISIC 31)

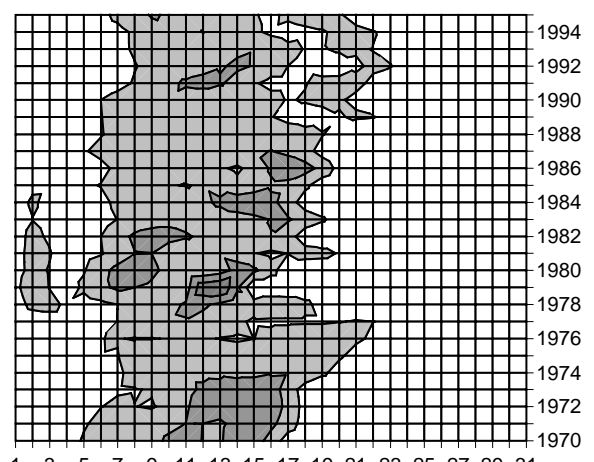

$\square 0-0.04 \square 0.04-0.08 \square 0.08-0.12 \square 0.12-0.16$
Radio, tv, telecom, semiconductors (ISIC 3832)

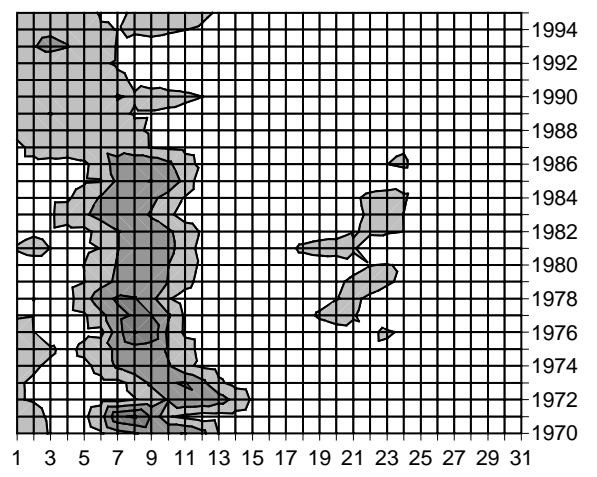

$\square 0-0.04 \square 0.04-0.08 \square 0.08-0.12 \square 0.12-0.16 \square 0.16-0.2$

Instruments (ISIC 385)

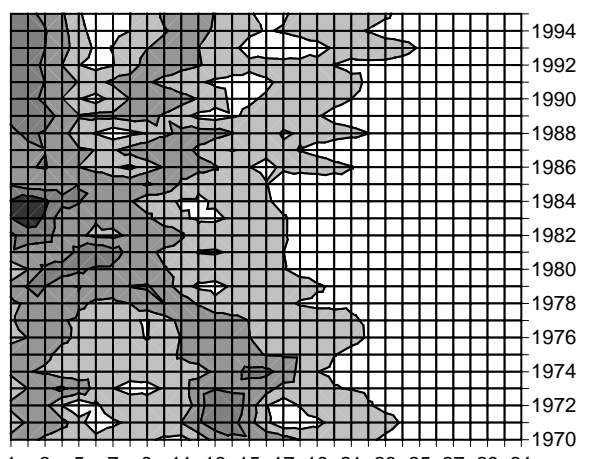

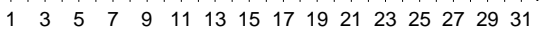

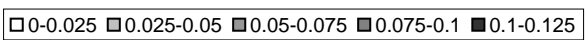

Textiles (ISIC 32)

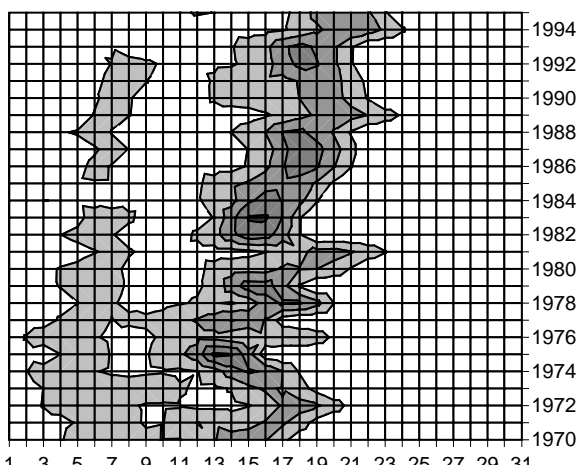

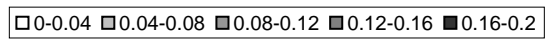


The two low-tech industries are included mainly for comparison. They show quite different behaviour, with food, drinks and tobacco being more or less stable, while textiles increasingly moves in the direction of a low-tech, low-cost strategy. Overall, however, the dynamic behaviour of the two low-tech sectors is much less spectacular and more "one-dimensional" than that observed in the four high-tech sectors.

Concluding, the figures illustrate the point that (especially) the high-tech markets do not seem to converge to a stable specialisation pattern of the type that would be expected on the basis of a theory that examines comparative advantages of countries as it would examine that of firms. Instead, markets, market shares and technology strategies seem to be constantly on the move. What the most recent data for two of the four high-tech sectors (computers, pharmaceuticals) show is that, in the most recent period, markets are converging to a double-peak structure, with market share concentrated in both the high-tech and lowtech/low-cost strategy areas. This seems to indicate that countries/firms that want to stay competitive in these markets are pushed into either a high-tech or a low-costs strategy. Other high-tech sectors do not seem to converge to such a situation, but instead either become more evenly distributed over the technology strategy space (instruments), or converge to a high-tech strategy peak.

\section{Drawing things together: towards an evolutionary interpretation of (future) growth in the world economy}

The empirical analysis of this paper started with a discussion about the characteristics of economic growth at the country level. It was concluded that changes in the trend rate of economic growth over time, or differences in the growth performance of countries are too numerous for the notion of a steady state to be interesting. Economic growth seems to be a process of constant transformation rather than one of adjustment to a long-run fixed target path. The most recent period (the last year included in the analysis is 1998) provides an interesting example of these issues. The 1990s show large differences in trend growth between countries, and, for some countries, the first signs of what might be a take-off of trend economic growth rates compared to the earlier decades which were characterised by slow growth.

Associated with this is an historically unique pattern in the indicators for convergence or divergence of GDP per capita in the OECD area. Convergence can be either be relative to the (OECD) average value of GDP per capita, or relative to the country with the highest value of this variable. For most of the $20^{\text {th }}$ century, and certainly for the post- 1950 period, the two indicators have shown very similar trends. The 1990s, however, break with this pattern. While convergence to the sample mean is still going on at a pace that is more or less comparable to that observed since the mid-1970s, divergence is taking place for the indicator based on differences relative to the leading country (in this case the United States). In other words, the United States seem to be "running away" from the other countries, while the latter are still, by and large, converging to the sample mean. The results on take-off of economic growth at the country level summarised at the start of this section suggest that, besides the United States, some other countries may also be "running away". These results are based on relatively few observations, so care must be taken in extrapolating them into the future.

However, there are also other omens of future divergence in the world economy. The re-estimation of Fagerberg's (1987) evolutionary growth model led to two major forms of transformation in the technologyeconomy domain. The first is that convergence (or catching-up) based on the assimilation of foreign technology is becoming an increasingly active process. For example, $R \& D$ now seems to be a crucial part of a catching-up strategy. This implies that undertaking $R \& D$ is no longer an activity that is unequivocally associated with moving the world technological frontier. The second conclusion is that the differences among countries in terms of "pure" (as indicated by patents, hence not including catching-up as covered in the previous point) technological competencies are becoming more and more important for explaining growth rate differentials. In other words, assimilating foreign technology increasingly requires active 
efforts, thus increasing the danger that countries will fall behind the world technological frontier, and technological differences across countries translate more easily into growth rate differentials. Both tendencies increase the probability of divergence in the world economy.

The evolutionary approaches to economic growth discussed here suggest that radical innovations are important for economic growth, and especially for changes in trend growth. With the empirical evidence and interpretation of this discussed above, one is tempted to conclude that information and communication technologies (ICT) are a recent example of such radical innovations. Indeed, input-output data for the United States suggests that the share of ICT in gross private fixed investment has been rising over the 1990s, and that ICT is now the most substantial component of total investment in the United States. Whether or not this is also the case for other OECD countries (Europe) is open to debate. I have not been able here to collect recent data on countries other than the United States. However, anecdotal evidence based on data on the diffusion of several types of ICT equipment and services (mobile telephones, computers, Internet, etc.) suggests that at least some parts of Europe are lagging behind the United States (Dalum, Freeman et al., 1999; OECD, 1999). This supports the interpretation of the results of the re-estimation of the Fagerberg model offered above.

Finally, I looked at adjustment of the OECD markets for high-technology content goods, in particular ICT hardware, instruments and pharmaceuticals. The evolution of market shares in combination with technology strategies (as measured by the "patenting content" of exports) was described by a series of histograms. This analysis seems to show that (again) over the 1990s, some degree of polarisation was occurring in these markets. Either the market seemed to be splitting into a segment served by technologyintensive producers and one served by low-cost-based producers, or it was becoming more concentrated in the direction of technology-intensive producers, with other producers losing market share. This suggests divergence in terms of technological competencies in combination with divergence in terms of trade performance.

In conclusion, the evolutionary interpretation of recent OECD growth patterns offered in this paper seems to suggest the possibility of divergence in the OECD area in the near future. More specifically, a scenario in which the developed world was split up into several "convergence clubs" (Baumol, 1986; Durlauf and Johnson, 1992), the leading one of which is formed by those countries that apply the radical innovation known as ICT most rapidly, does not strike me as unlikely in the middle-to-long run. Lagging behind the leading "club", will be several other clubs which rely either on slow (compared to the first club) assimilation of knowledge spillovers from abroad, or on low-cost strategies based on low wages rather than on technological competencies. One interpretation of recent European regional growth patterns is that a similar process has been going on in that part of the world since the early 1980s (Fagerberg and Verspagen, 1996; Fagerberg, Verspagen and Caniëls, 1997). But then again, in an evolutionary world, the future is uncertain. 


\section{NOTES}

1. Jan Fagerberg, Bart Los, Alessandro Nuvolari and Eddy Szirmai provided valuable comments on an earlier draft. Controversial opinions and remaining errors are my own.

2. Henceforth, I will group new growth theory (or endogenous growth theory) under the term neo-classical economics.

3. Often, the statistical categories used to describe industries are not very adequate for measuring the impact of new technologies. Thus, one would generally expect that the extent of structural change going on in the economy is larger than what surfaces when looking at the statistics.

4. The specific result of the Kalman filter estimations depend on a number of parameters, of which the variance factors in the transition and measurement equations are two important ones. I inferred the variance factor in the transition equation from a number of initial estimations, according to the procedure described as "bootstrapping a variance for the transition equation" in the TSP 4.4 Reference Manual under the KALMAN command. I used defaults for all other estimation parameters, among which the identity matrix for the transition factor in the measurement equation. However, the results are not very sensitive for these parameters, especially not for the years in the graphs.

5. The updates were taken from the GGDC Total Economy Database, University of Groningen, Fourth Quarter 1999, http://www.eco.rug.nl/ggdc.

6. West Germany only.

7. I compared data on total external patenting and data on patenting in the US to each other for the OECD countries in the sample. There are three countries that are clear outliers in the total sample for the complete period under consideration. These are the United States (because of a "home market effect"), Canada (similar) and Japan. I adjusted the data for these three countries downwardly in such a way that the ratio between their value for total external patenting and the mean value of that variable of Germany, the United Kingdom and France is replicated in the US patenting data. Details available on request.

8. Compared to Fagerberg, the present sample excludes India, Mexico, Brazil, Argentina, but adds Malaysia, Philippines, Turkey, Singapore and Thailand.

9. I do not test Fagerberg's double ln relationship.

10. The GDP deflator is used, and R\&D expenditures are total expenditures (GERD).

11. See Cohen and Levinthal (1989) for a theoretical exposition of a similar argument at the firm level, and Fagerberg (1988) or Fagerberg (1994) for related arguments on assimilating spillovers at the country level.

12. See, for example, Dalum, Freeman et al. (1999), for a fuller account of the economic context of the takeoff of ICT.

13. Two tables were used (1992 and 1996), both of which were taken from the Bureau of Economic Analysis' Web site (February 2000). These two tables were the most recent ones available at the time of writing. I used the commodity by commodity total requirements matrix, and treated it as the inverse Leontief matrix from regular input-output analysis.

14. I would rather have used only a part of this group, i.e. communication equipment. 
15. Apart from the fact that a capital flow matrix was not available, this was done to bring out the embodiment of ICT. Intermediary use can most readily be associated with embodiment because it most often concerns components that can actually be found inside the equipment. Of course, this is much less obvious when related to services.

16. Sectors with strong indirect production effects are wholesale trade; business and professional services; primary metals; real estate; lumber and wood, trucks. The electronic components sector (listed in Table 4) is also a sector with strong indirect effects, see below.

17. All trade data used in this section are taken from the OECD STAN Bilateral Trade Database. I used imports data.

18. The additional countries are Korea (now a Member of the OECD), Hong Kong (China), Indonesia, India, Malaysia, the Philippines, Singapore, Thailand, and Chinese Taipei. Hence, as was the case in Section 4, this section puts some emphasis on the Asian NICs.

19. For countries without patents, this leads to joint ranks at the lower spectrum of the distribution.

20. These diagrams resemble those used by Silverberg and Verspagen $(1994,1995)$ in the analysis of an evolutionary growth model. 


\section{REFERENCES}

Abramovitz, M.A. and P.A. David (1996), "Convergence and Deferred Catch-up: Productivity Leadership and the Waning of American Exceptionalism”, in R. Landau, T. Taylor and G. Wright (eds.), The Mosaic of Economic Growth, Stanford University Press, Stanford, pp. 21-62.

Aghion, P. and P. Howitt (1992), “A Model of Growth Through Creative Destruction”, Econometrica 60, pp. 323-351.

Baumol, W.J. (1986), "Productivity Growth, Convergence, and Welfare: What the Long Run Data Show", American Economic Review 76, pp. 1072-1085.

Benhabib, J. and M.M. Spiegel (1994), "The Role of Human Capital in Economic Development: Evidence from Aggregate Cross-country Data”, Journal of Monetary Economics 34, pp. 143-173.

Cohen, W.M. and D.A. Levinthal (1989), "Innovation and Learning: The Two Faces of R\&D”, Economic Journal 99, pp. 569-596.

Crafts, N. and T.C. Mills (1996), "Europe's Golden Age: An Econometric Investigation of Changing Trend Rates of Growth" in N. Crafts and B. v. Ark (eds.), Quantitative Aspects of Post-war European Economic Growth, Cambridge University Press, Cambridge, pp. 415-431.

Dalum, B., C. Freeman, R. Simonetti, B. Verspagen and N. Von Tunzelmann (1999), "Europe and the Information and Communications Technologies Revolution", in J. Fagerberg, P. Guerrieri and B. Verspagen (eds.), The Economic Challenge to Europe. Adapting to Innovation Based Growth, Edward Elgar, Aldershot, pp. 106-129.

David, P. (1990), “The Dynamo and the Computer: An Historical Perspective on the Modern Productivity Paradox”, American Economic Review 80, pp. 355-361.

Dosi, G. (1982), "Technological Paradigms and Technological Trajectories", Research Policy 11, pp. 147-162.

Dosi, G. (1984), Technical Change and Industrial Transformation, Macmillan, London.

Dosi, G., O. Marsili, L. Orsenigo and R. Salvatore (1995), "Learning, Market Selection and the Evolution of Industrial Structures", Small Business Economics 7, pp. 411-436.

Dosi, G., K. Pavitt and L. Soete (1990), The Economics of Technological Change and International Trade, Wheatsheaf, Brighton.

Durlauf, S.N. and P.A. Johnson (1992), "Local versus Global Convergence across National Economies", NBER Working Paper. 
Fagerberg, J. (1987), “A Technology Gap Approach to Why Growth Rates Differ”, Research Policy 16, pp. 87-99.

Fagerberg, J. (1988a), “International Competitiveness”, Economic Journal, pp. 355-374.

Fagerberg, J. (1988b), "Why Growth Rates Differ", in G. Dosi, C. Freeman, R. R. Nelson, G. Silverberg and L. Soete (eds.), Technical Change and Economic Theory,. London, Pinter, pp. 87-99.

Fagerberg, J. (1994), "Technology and International Differences in Growth Rates", Journal of Economic Literature 32, pp. 1147-1175.

Fagerberg, J. (forthcoming, 2000), “Technological Progress, Structural Change and Productivity Growth: A Comparative Study", Structural Change and Economic Dynamics.

Fagerberg, J. and B. Verspagen (1996), "Heading for Divergence? Regional Growth in Europe Reconsidered", Journal of Common Market Studies 34, pp. 431-448.

Fagerberg, J., B. Verspagen, and M. Caniëls (1997), "Technology, Growth and Unemployment across European Regions", Regional Studies 31, pp. 457-466.

Fagerberg, J., P. Guerrieri and B. Verspagen (1999), Europe - A Long View”, in J. Fagerberg, P. Guerrieri and B. Verspagen (eds.), The Economic Challenge to Europe. Adapting to Innovation Based Growth, Edward Elgar, Aldershot, pp. 1-20.

Freeman, C. (1982), The Economics of Industrial Innovation, Pinter Publishers, London.

Freeman, C., J. Clark and L. Soete (1982), Unemployment and Technical Innovation, Pinter, London.

Freeman, C. and L. Soete (eds.) (1987), Technical Change and Full Employment, Basil Blackwell, London.

Freeman, C. and L. Soete (1990), "Fast Structural Change and Slow Productivity Change: Some Paradoxes in the Economics of Information Technology", Structural Change and Economic Dynamics 1, pp. 225-242.

Freeman, C. and L. Soete (1997), The Economics of Industrial Innovation. 3rd Edition, Pinter, London and Washington.

Härdle, W. (1990), Applied Nonparametric Regression, Cambridge University Press, Cambridge.

Heertje, A. (1993), "Neo-Schumpeterians and Economic Theory", in Magnusson (ed.), Evolutionary Approaches to Economic Theory, Kluwer, Dordrecht, pp. 265-276.

Helpman, E.H. and M. Trajtenberg (1994), “A Time to Sow and a Time to Reap: Growth based on General Purpose Technologies", NBER Working Paper No. 4854.

Katsoulacos, Y. (1986), The Employment Effect of Technical Change. A Theoretical Study of New Technology and the Labour Market, Wheatsheaf, Brighton.

Kleinknecht, A. (1987), Innovation Patterns in Crisis and Prosperity. Schumpeter's Long Cycle Reconsidered, Macmillan, London. 
Kortum, S. (1997), "Research, Patenting and Technological Change”, Econometrica 65, pp. 1389-1419.

Los, B. (1999), The Impact of Research and Development on Economic Growth and Structural Change, $\mathrm{PhD}$ thesis, University of Twente, Enschede.

Lucas, R.E.B. (1988), “On the Mechanics of Economic Development”, Journal of Monetary Economics 22 , pp. 3-42.

Maddison, A. (1995), Monitoring the World Economy 1820-1992, OECD Development Centre, Paris.

Nelson, R.R. and S.G. Winter (1982), An Evolutionary Theory of Economic Change, Harvard University Press, Cambridge, MA.

OECD (1999), The Knowledge-based Economy. A Set of Facts and Figures, OECD, Paris.

OECD (2000), A New Economy? The Changing Role of Innovation and Information Technology in Growth, OECD, Paris.

OECD/EUROSTAT (1995), "Classification of High-technology Products and Industries", OECD, Paris, mimeo.

Oliner, S.D. and D.E. Sichel (1994), "Computers and Output Growth Revisited: How Big the Puzzle?", Brookings Papers on Economic Activity, pp. 273-334.

Pavitt, K. and L. Soete (1982), "International Differences in Economic Growth and the International Location of Innovation", in H. Giersch (ed.), Emerging Technologies: The Consequences for Economic Growth, Structural Change and Employment, Mohr, Tuebingen, pp. 105-133.

Perez, C. (1983), "Structural Change and the Assimilation of New Technologies in the Economic and Social Systems", Futures 15, pp. 357-375.

Petit, P. and L. Soete (2000), "Technical Change and Employment Growth in Services: Analytical and Policy Challenges", in P. Petit and L. Soete (eds.), Technology and the Future of European Employment, Edward Elgar, Aldershot.

Rebelo, S. (1991), “Long-Run Policy Analysis and Long-Run Growth”, Journal of Political Economy 99, pp. 500-521.

Romer, P.M. (1990), "Endogenous Technological Change", Journal of Political Economy 98, pp. S71-S102.

Saxenian, A. (1994), Regional Advantage. Culture and Competition in Silicon Valley and Route 128, Harvard University Press, Cambridge MA and London.

Schumpeter, J.A. (1912), Theorie der wirtschaftlichen Entwickelung, Duncker \& Humboldt, Leipzig.

Schumpeter, J.A. (1939), Business Cycles: A Theoretical, Historical and Statistical Analysis of the Capitalist Process, McGraw-Hill, New York.

Silverberg, G. (1988), "Modelling Economic Dynamics and Technical Change: Mathematical Approaches to Self-Organisation and Evolution", in G. Dosi, C. Freeman, R. Nelson, G. Silverberg and L. Soete (eds.), Technical Change and Economic Theory, Pinter, London, pp. 531-559. 
Silverberg, G. and D. Lehnert (1994), "Growth Fluctuations in an Evolutionary Model of Creative Destruction", in G. Silverberg and L. Soete (eds.), The Economics of Growth and Technical Change. technologies, Nations, Agents, Edward Elgar, Aldershot, pp. 74-108.

Silverberg, G. and B. Verspagen (1994), "Learning, Innovation and Economic Growth. A Long Run Model of Industrial Dynamics", Industrial and Corporate Change 3, pp. 199-223.

Silverberg, G. and B. Verspagen (1995), "Long-term Cyclical Variations of Catching Up and Falling Behind. An Evolutionary Model”, Journal of Evolutiuonary Economics 5, pp. 209-227.

Silverberg, G. and B. Verspagen (1998), "Economic Growth and Economic Evolution: A Modeling Perspective", in F. Schweitzer and G. Silverberg (eds.), Selbsorganisation. Jahrbuch für Komplexität in den Natur-, Sozial- und Geisteswissenschaften, Duncker \& Humblot, Berlin.

Solow, R.M. (1970), Growth Theory: An Exposition, Oxford University Press, Oxford.

Ten Raa, T. and E.N. Wolff (1999), Engines of Growth in the US Economy, ECIS/SCED Conference on Economic Growth, Trade and Technology, 3-4 October, Eindhoven.

Triplett, J.E. (1996), "High-tech Industry Productivity and Hedonic Price Indices", Industry Productivity: International Comparisons and Measurement Issues, OECD, Paris.

Van Duijn, J.J. (1983), The Long Wave in Economic Life, Allen \& Unwin, London.

Van Meijl, H. (1995), "Endogenous Technological Change: The Case of Information Technology. Theoretical Considerations and Empirical Results", MERIT, University of Limburg, Maastricht, p. 289.

Von Tunzelmann, N. (1995), Technology and Industrial Progress. The Foundations of Economic Growth, Edward Elgar, Cheltenham. 